\title{
Cheating on Their Taxes: When Are Tax Limitations Effective at Limiting State Taxes, Expenditures, and Budgets?
}

\author{
COLIN H. McCUBBINS* \\ MATHEW D. McCUBBINS**
}

\section{INTRODUCTION}

Delegation and agency are ubiquitous in a democracy. How a democracy addresses these matters determines the quality of the democracy and the impacts the kinds of policies implemented by the lawmaking bodies produce. Central to these policies is the ability of the government to generate revenue. To this end, citizens often seek to limit their government's ability to lay and collect taxes. America's long history is reflective of this matter, as voters have waged continuous battles to keep taxes low. The earliest of these battles manifested themselves in the structure of the Articles of Confederation, which granted the federal government no ability to lay or collect taxes. ${ }^{1}$ Instead, apportionment and collection of taxes fell to the individual states, a system that provided woefully inadequate amounts of revenue. Although this was effectively remedied with the eventual adoption of the Constitution, Article 1 still effectively limited tax collections to a head tax, rather than the ability to tax other economic entities, such as property. ${ }^{2}$ Additionally, many states have adopted tax limitations that restrict tax collections by the state government, local governments, or both. ${ }^{3}$

The key question is when will elected representatives faithfully follow the wishes of their electors? In all republican forms of government the first means by which the people manage their collective agency problem is through frequent elections. In the United States, there is also a division of power and a competitive division of purpose among elected representatives. As Madison famously argued, "the

\footnotetext{
* Ph.D. Candidate, Stanford University.

** Professor of Political Science and Law, Duke University.

1 Articles of Confederation of 1781, art. VIII, para. 2.

2 U.S. Const. art. 1, § 2, cl. 2.

3 See, e.g., Cal. Const. art. XIII A, $\S \S 1,3$.
} 
great security against a gradual concentration of the several powers in the same department, consists in giving to those who administer each department, the necessary constitutional means, and personal motives, to resist encroachments of the others. . . . Ambition must be made to counteract ambition." 4 State governments have taken this one step further by giving voters indirect lawmaking power through referendum or direct lawmaking power through initiatives and, in some cases, both. This lawmaking procedure, theoretically, allows citizens to counteract their representative's ambitions with their own.

Revenue is central to the function of government. As a result, there is incentive within the government to continually raise these levels. It is unsurprising, then, that citizens have sought to limit the fiscal inputs of their governments, trying to tie their hands by limiting levels of taxation, expenditure, and debt. The earliest laws in the United States requiring citizen approval were assessment levies, to build common goods such as streets and water drainage systems. ${ }^{5}$ Later, in response to frequent and widespread municipal and state bankruptcies, citizens sought to limit public debt. ${ }^{6}$ The twin banking panics of 1837 and 1857 , and the massive, reckless borrowing in the early part of the nineteenth century led to new constitutional debt limitations whereby a state's voters would be directly responsible for approving new issuances of public debt. ${ }^{7}$ New York, for example, adopted the "People's Resolution" at a constitutional convention in 1846, which sought to limit the state's ability to borrow on the full faith and credit of the state and by regulating such borrowing to be approved by the people via referendum. ${ }^{8}$

In the "tax revolt" of the late 1970's that continues today, voters have sought to require voter approval, not just for debt issued on the full faith and credit of the state, but also for the imposition of property and income taxes. 9 These were passed in reaction to an increase in the burden of particular taxes, such as those on real property, caused by periods of high inflation or economic downturn. ${ }^{10}$ These limitations were often passed on the same ballot as other measures that attempted to limit expenditures, or to require a balanced budget, and in some instances to limit terms of office for state representa-

4 The Federalist No. 51, at 245 (James Madison) (Hallowell ed., 1837).

5 Vladimir Kogan \& Mathew D. McCubbins, The Problem with Being Special: Democratic Values and Special Assessments, 14 Pub. Works Mgmt. \& Pol'y 4, 7-8 (2009).

6 Paul Studenski \& Herman E. Krooss, Financial History of the United States 132 (1st ed. 1952).

7 Id.

8 Id. at 132 n.7.

9 See, e.g., Robert Lindsey, California Tax Revolt: Lesson for Legislators, N.Y. Times, June 12, 1978, at B10.

10 See, e.g., id. 
tives. ${ }^{11}$ These measures often have strong interactions with tax limitations, producing connected networks of procedure that have been thought to drastically change fiscal behavior in the states. ${ }^{12}$

Yet there seems to be a set of conflicting interests that underpin the effectiveness of these limitations. Within this set of interests, legislatures have more power in this relationship because they hold the power of implementation. Legislatures can pass budgets for and direct agency action on their passed policies. Citizens have no such means. In fact, citizens must wait for the legislatures themselves to implement policies passed by initiative. Similarly, while short-term oversight of implementation may be feasible for voters, long-term oversight is extraordinarily difficult, especially when the incentives of future agents run counter to those expressed in the past initiative. This oversight is even more troublesome given that responsibility for monitoring implementation is dispersed enough that "fire alarms" need to be extremely large in order to garner a sufficient reaction. As such, initiatives provide neither an overseer nor a veto-player to ward off legislative action. Instead, the people, through the initiative, are setting the fox to guard the henhouse.

We are, of course, not the first to recognize this implementation problem. Yet, there are questions that need to be answered about tax limitations. Do these measures succeed in limiting taxes? The answer is: yes ... sometimes. As they are often passed simultaneously with other fiscal initiatives, we may see the effect of tax limitations of state spending or debt. When and where are these measures likely to be successful? That question is harder to answer. The first is when the metaphorical fox has incentives to successfully guard the henhouse. This could take the form of a favorable political party holding office, one that supports tax limitations. An example of this is the Taxpayers Bill of Rights (TABOR) in Colorado. ${ }^{13}$ The second is when implementation of an initiative is decentralized and does not rely exclusively on the legislature, as is the case with Proposition 13 in California. ${ }^{14}$ Yet, despite these stipulations, it may be that the implementation is almost too difficult to overcome. Indeed, our results call into question the effectiveness of both of these determinants.

11 For example, a term limits measure as well as a supermajority limitation on raising taxes were passed on the same ballot in 1992. See Ballotpedia, Arizona Term Limits, Proposition 107 (1992), http://ballotpedia.org/Arizona_Term_Limits,_Proposition_107_(1992); Ballotpedia, Arizona Two-Thirds for Taxes Amendment, Proposition 108 (1992), http://bal lotpedia.org/Arizona_Two-thirds_For_Taxes_Amendment,_Proposition_108_(1992).

12 See Michael J. New, U.S. State Tax and Expenditure Limitations: A Comparative Political Analysis, 10 St. Pol. \& Pol'y Q. 25 (2010).

13 Colo. Const. art. X, \& 20.

14 Cal. Const. art. XIII A. 
In order to answer these questions, we examine a complex of state fiscal policies, expenditures, and debt, employing a novel research design: synthetic case control. ${ }^{15}$ This is similar to a comparable series design. The key problem is estimating the counterfactual policy outcomes that would have occurred had no tax limitation enacted been enacted. The synthetic control method generates these counterfactual fiscal outcomes and allows us to make direct comparisons between states that have enacted tax limitations and those that have not on a state-by-state and policy-by-policy basis. While this method provides us with statistics power similar to a panel study, it is, in essence, a case study method. By using a case control method rather than a panel study, though, we are able to derive different estimates of the effects of tax limitations that differ by state and policy, rather than restricting ourselves to estimate a single unified effect that is assumed to be the same for all states across all years. Using this method, we corroborate earlier findings by Thad Kousser, Mathew McCubbins, and Kaj Rozga, ${ }^{16}$ as well as Kousser, McCubbins, and Ellen Moule ${ }^{17}$ that fiscal initiatives are indeed ineffective at their stated goal of reducing taxes, expenditures, and budgets. While frequent elections may mitigate losses due to agency, as Madison describes, the enactment of tax limitations do not share these characteristics.

Our Article is structured as follows: First we discuss the extant literature on initiatives, discussing specifically the closely related tax and expenditure limitations literature. Second, we discuss our method of analysis (synthetic control) and the benefits this method provides for our study. Third, we discuss our results, highlighting interesting cases for explanation. Finally we conclude. Our conclusions drawn here lead us to question the mechanisms behind some of the most important findings in the literature on initiatives.

\section{Hybrid Democracy and Tax and Expenditure Limitations}

There is a divide in the state politics literature about the effect of initiatives. Some argue that initiatives provide a unique way for vot-

15 See generally Alberto Abadie, Alexis Diamond \& Jens Hainmueller, Synthetic Control Methods for Comparative Case Studies: Estimating the Effect of California's Tobacco Control Program, 105 J. Am. Stat. Ass'n 493, 494-96 (2010) (explaining the use of synthetic control methods in comparative case studies).

16 Thad Kousser, Mathew D. McCubbins \& Kaj Rozga, When Does the Ballot Box Limit the Budget? Politics and Spending Limits in California, Colorado, Utah, and Washington, in Fiscal Challenges: An Interdisciplinary Approach to Budget Policy 290, 318 (Elizabeth Garrett, Elizabeth A. Grady \& Howell E. Jackson eds., 2008).

17 Thad Kousser, Mathew D. McCubbins \& Ellen Moule, For Whom the TEL Tolls: Can State Tax and Expenditure Limits Effectively Reduce Spending?, 8 St. Pol. \& Pol'y Q. 331, 354-55 (2008). 
ers to check legislative power. ${ }^{18}$ Elizabeth Gerber, for example, presents initiatives as a policymaking game between voters, legislatures, and initiative proponents. ${ }^{19}$ Here, initiative proposers have incentives to pass legislation that would move policy away from the legislature' ${ }^{20}$ ideal point. ${ }^{21}$ Legislatures, in turn, will pre-empt proposed initiatives by passing legislation that would take its place.22 This, however, has the side effect of moving policy towards the median voter anyway. ${ }^{23}$ Initiatives then also act as agenda control mechanisms, forcing the legislature to vote on topical policy rather than on policy that is nonrepresentative. ${ }^{24}$ The mere threat of initiatives, consequently, moves policy, ${ }^{25}$ including differences in levels of spending and taxation. ${ }^{26}$ This, in turn, demonstrates that initiatives can mitigate the aforementioned agency problems.

Some, however, argue that the initiative process is more symbolic than real. ${ }^{27}$ The core of the argument is that initiatives are difficult, if

18 See Elisabeth R. Gerber, The Populist Paradox 37-58 (1999) [hereinafter Populist Paradox]; John G. Matsusaka, For the Many or the Few: The Initiative, Public Policy, and American Democracy 128-46 (2004); Todd Donovan \& Shaun Bowler, An Overview of Direct Democracy in the American States, in Citizens as Legislators 1, 13-16 (Shaun Bowler, Todd Donovan \& Caroline J. Tolbert eds., 1998); Elisabeth R. Gerber, Legislative Response to the Threat of Popular Initiatives, 40 Am. J. Pol. Sci. 99, 124 (1996) [hereinafter Legislative Response]; Arthur Lupia \& John G. Matsusaka, Direct Democracy: New Approaches to Old Questions, 7 Ann. Rev. Pol. Sci. 463, 469-80 (2004); John G, Matsusaka, Fiscal Effects of the Voter Initiative: Evidence from the Last 30 Years, $103 \mathrm{~J}$. Pol. Econ. 587, 620-21 (1995); John G. Matsusaka, Fiscal Effects of the Voter Initiative in the First Half of the Twentieth Century, 43 J.L. \& Econ. 619, 641-42 (2000); John G. Matsusaka \& Nolan M. McCarty, Political Resource Allocation: Benefits and Costs of Voter Initiatives, 17 J.L. Econ. \& Org. 413, 444-46 (2001).

19 Gerber, Legislative Response, note 18, at 101-02.

20 This need not apply only to the legislature as a whole. Many pieces of state governments can hold blocking power, from governors to extreme wings of parties. As such, oftentimes the only way to get around this type of blocking is through the passage of initiatives.

21 Gerber, Legislative Response, note 18, at 102.

$22 \mathrm{Id}$

23 Id. at 109.

24 Gerber, Populist Paradox, note 18, at 121.

25 Id. at 126.

26 Matsusaka \& McCarty, note 18 , at 444.

27 See Elisabeth R. Gerber, Arthur Lupia, Mathew D. McCubbins \& D. Roderick Kiewiet, Stealing the Initiative: How State Government Responds to Direct Democracy 109-10 (2001) [hereinafter Stealing]; Kousser et al,, note 16, at 354; cf. Valentina A. Bali, Implementing Popular Initiatives: What Matters for Compliance?, 65 J. Pol. 1130, 1141-42 (2003) (finding that compliance with initiatives is reliant on the implementing leadership and continued voter support); Elizabeth Garrett \& Mathew D. McCubbins, When Voters Make Laws: How Direct Democracy Is Shaping American Cities, 13 Pub. Works Mgmt. \& Pol'y 39, 57-58 (2008) (arguing that referendums may have negative welfare effects); Elisabeth R. Gerber, Arthur Lupia \& Mathew D. McCubbins, When Does Government Limit the Impact of Voter Initiatives? The Politics of Implementation and Enforcement, $66 \mathrm{~J}$. Pol. 43, 59-60 (2004) [hereinafter Politics] (outlining conditions impacting an initiative's degree of success in implementation). 
not impossible, for the public to implement and oversee. ${ }^{28}$ This is especially so for limits on expenditures, budgets, and broad categories of revenue, as money is fungible and can easily move from one account to another while simultaneously complying with the letter of the law. ${ }^{29}$ For the logic behind this argument, consider the following: Gerber notes that initiatives that are passed are more likely to be extreme in nature because, if they were not, they would likely fall inside the legislature's preference bounds and would have been enacted without resorting to an initiative. ${ }^{30}$ Initiative campaigns are also expensive, ${ }^{31}$ so the expected payoff of the passed initiative needs to outweigh the political cost of the campaign. Building on work by Thomas Romer and Howard Rosenthal, ${ }^{32}$ Roderick Kiewiet and Mathew McCubbins discuss that this is precisely the type of situation where agent noncompliance is most likely, because the legislature is the implementing agent and at least some decisive part is likely to be hostile to the goals of the initiative. ${ }^{33}$

The literature on the effects of tax and expenditure limitations, of which our study is a part, reflects the division in the literature on initiatives. Part of the division, however, appears to arise merely from a methodological divide. The traditional starting point for analyzing tax and expenditure limitations is cross-state comparisons of fiscal activity over time. ${ }^{34}$ Many of these studies start with large panels and estimate the average effects of tax and expenditure limitations through use of pooled regression models. Typically, these pooled regressions

28 See, e.g., Gerber et al., Stealing, note 27, at 109.

29 See Kousser et al., note 16, at 351-52.

30 Gerber, Populist Paradox, note 18, at 34-36; Gerber, Legislative Response, note 18, at $106-07$.

31 Elizabeth Garrett \& Elisabeth R. Gerber, Money in the Initiative and Referendum Process: Evidence of Its Effects and Prospects for Reform, in The Battle over Citizen Lawmaking 73, 73 (M. Dane Waters ed., 2001).

32 Thomas Romer \& Howard Rosenthal, Political Resource Allocation, Controlled Agendas, and the Status Quo, 33 Pub. Choice, no. 4 (1978).

33 D. Roderick Kiewiet \& Mathew D. McCubbins, The Logic of Delegation 26-27 (1991).

34 See Burton A. Abram \& William R. Dougan, The Effects of Constitutional Restraints on Government Spending, 49 Pub. Choice 101, 113 (1986); Dale Bails \& Margaret A. Tieslau, The Impact of Fiscal Constitutions on State and Local Expenditures, 20 Cato J. 255, 261-64 (2000); Harold W. Elder, Exploring the Tax Revolt: An Analysis of the Effects of State Tax and Expenditure Limitation Laws, 20 Pub. Fin. Q. 47 (1992); Daniel Mullins \& Phillip G. Joyce, Tax and Expenditure Limitations and State and Local Fiscal Structure: An Empirical Assessment, Pub. Budgeting \& Fin., Mar. 1996, at 75, 79; Daniel R. Mullins, Tax Expenditure Limitations and the Fiscal Response of Local Government: Asymmetric Intra-Local Fiscal Efforts, Pub. Budgeting \& Fin., Dec. 2004, at 111, 119-20; Michael J. New, Limiting Government Through Direct Democracy: The Case of State Tax and Expenditure Limitations, Cato Pol'y Analysis, Dec. 13, 2001, at 1, 3-4; Ronald J. Shadbegian, Do Tax and Expenditure Limitations Affect the Size and Growth of State Government?, 14 Contemporary Econ. Pol'y 22 (1996). 
show moderate to strong directional effects on state finances after the passage of a tax and expenditure limitation. For example, Harold Elder states that "there is strong evidence of a reduction of tax growth in states with expenditure limitations".35 Dale Bails and Margaret Tieslau report a reduction of $\$ 41$ in per capita expenditures in states with tax and expenditure limitations. ${ }^{36}$ Michael New presents a more nuanced analysis that divides tax and expenditure limitation states based on method of its passage, finding that states where tax and expenditure limitations passed by initiative saw a reduction in average per capita expenditures by $\$ 16.29$ in each year following implementation while, conversely, states where tax and expenditure limitations were enacted by the legislature actually saw an increase in expenditures. ${ }^{37}$ Meanwhile, others have argued, using similar methods, that the effects of tax and expenditure limitations are negligible or unobservable. ${ }^{38}$

Each large panel analysis, however, suffers from a similar methodological problem. First, these initiatives are not comparable across states. Factors that will yield different legislation that will be implemented in different ways include: the initiative processes for placing initiatives on the ballot, how frequently they are on the ballot, whether or not competing initiatives were considered, and whether or not the state's political parties supported or opposed the initiative. This fact violates the fundamentals of analysis of causal inference since we cannot attribute the effects of any changes in government spending to a single parameter estimate. ${ }^{39}$ Second, the effect of any one initiative is muted when a pooled analysis is undertaken. It is impossible to differentiate, in these cases, whether the parameter estimates are driven by each state sharing a very similar effect on fiscal behavior or if an exceedingly large effect in any one state is driving the whole panel estimate towards statistical significance. This is the main reason why we champion the use of state-by-state analysis.

We are, of course, not the only advocates of case studies in looking at the effect of state policy. Typically, state-by-state analysis does not show the same strong effects as large panel studies. For example, studies by James Cox and David Lowery and Tyson King-Meadows and Lowery perform state-by-state regression analysis for three tax and expenditure limitation states, finding little evidence of tax and ex-

35 Elder, note 34 , at 48 .

36 Bails \& Tieslau, note 34, at 270.

37 New, note 34 , at 8 .

38 Abrams \& Dougan, note 34, at 112-13; Mullins \& Joyce, note 34, at 95, 97.

39 Technically, we do not have a homogeneous "treatment" across our "units." Moreover, our units are vastly different and may not be comparable. 
penditure limitation success in decreasing spending.40 Dale Bails takes the differences in mean percent change of spending and taxation between non-tax-and-expenditure-limitation and tax-and-expenditure-limitation-implemented states, finding no differences. ${ }^{41}$ Phillip Joyce and Daniel Mullins find only short-term declines in revenues and expenditures in tax-and-expenditure-limitation states but these states have tax increases that, over time, negate the short-term reductions. ${ }^{42}$ Kousser, McCubbins, and Moule perform both a large panel difference-in-differences estimation and individual state level regressions for each tax-and-expenditure-limitation state, creating a composite counterfactual for each state and finding that, of those states that have tax and expenditure limitations, only Colorado's TABOR seems to have a non-negligible effect. ${ }^{43}$

There have been several predictions for the success of tax expenditure limitations and, likewise, initiatives in general. Many of these have to do with legal provisions in the implementation of these measures that specify targeted revenue or expenditure streams. Dean Stansel, for example, discusses several methods by which tax and expenditure limitations can be made more effective, including expanding their provisions to cover types of local spending and nontax revenue sources. ${ }^{44}$ New argues that limitations passed by initiative are likely to be more stringent than ones passed by the legislature, which predicts their success. ${ }^{45}$ On the other hand, predictions made by two studies indicate exactly the opposite; that tax and expenditure limitations passed by initiative are less likely to be faithfully implemented than those enacted through the usual lawmaking process. ${ }^{46}$ Kousser, McCubbins, and Moule discuss TABOR's effectiveness, as it is the only tax and expenditure limitation that seems to display even marginal effects. TABOR is the most stringent measure according to their analysis, as well as having generally favorable political conditions, in

40 James Cox \& David Lowery, The Impact of the Tax Revolt Era State Fiscal Caps, 71 Soc. Sci. Q. 492, 498-506 (1990); Tyson King-Meadows \& David Lowery, The Impact of the Tax Revolt Era State Fiscal Caps: A Research Update, Pub. Budgeting \& Fin., Mar. 1996, at $102,103-08$.

41 Dail Bails, The Effectiveness of Tax-Expenditure Limitations: A Re-Evaluation, 49 Am. J. Econ. \& Soc. 223, 228-30 (1990).

42 Phillip G. Joyce \& Daniel R. Mullins, The Changing Fiscal Structure of the State and Local Public Sectors: The Impact of Tax and Expenditures Limitations, 51 Pub. Admin. Rev. 240, 240 (1991).

43 Kousser et al., note 17, at 336-41, 345-46.

44 Dean Stansel, Taming Leviathan: Are Tax and Spending Limits the Answer?, Cato Pol'y Analysis, July 5, 1994, at 1, 17.

45 New, note 34, at 5-6.

${ }^{46}$ See Gerber et al., Stealing, note 27, at 19-20; Gerber et al., Politics, note 27, at 52-54. 
that the enacting parties stayed in power for most of the term during which TABOR was in effect. ${ }^{47}$

Despite this recent scholarship on tax and expenditure limitations, there has been very little analysis of pure tax limitations, which is the goal of our analysis. The typical way they are discussed is in policy pieces focusing on case studies of individual tax limitations. For example, in a previous paper, we discussed the impacts of California's Proposition 13. We concluded that, although there were some unsurprising effects of the proposition on the amount of per capita property taxes collected, the state government was able to circumvent the limitation by turning to various other revenue streams, such as charges and fees (which, ironically, are largely pegged to real parcels). ${ }^{48} \mathrm{We}$ hope to extend this sort of analysis here to other states' tax limitations, as well as updating the way in which the counterfactual level of fiscal policy is estimated, thus giving us a better, more defendable estimate of the effect of various attempts to limit taxes. We now turn to a discussion of synthetic controls.

\section{Methodology}

In order to analyze the effectiveness of tax limitations at reducing taxes, expenditures, and budgets, we use the synthetic control method introduced by Alberto Abadie, Alexis Diamond, and Jens Hainmueller. ${ }^{49}$ As just discussed, the heterogeneous nature of the writing and implementation of tax limitations poses a methodological problem. Large panel regression, in particular difference-in-differences (DiD) estimation, both perform poorly because of this heterogeneity, as these types of panel regressions require homogeneous effects, together with identical units or nearly so, to tease out causal effects. Conversely, single state case studies are troublesome due to lack of clear counterfactuals. For example, using structural break analysis as in Kousser, McCubbins, and Moule, effectively compares each state to its own past behavior. ${ }^{50}$ While this is generally closer and the issues of heterogeneity in tax limitations and states are dissipated, the synthetic control method affords us the opportunity to estimate the effect size of a given law.

The method, in short, constructs a synthetic counterfactual for each tax limitation state using a weighted match of comparable states that

47 Kousser et al., note 17, at 352-54.

48 Colin H. McCubbins \& Mathew D. McCubbins, Proposition 13 and the California Fiscal Shell Game, Cal. J. Pol. Pol'y, Feb. 2010, at 1, 22.

49 Abadie et al., note 15, at 494-97 (discussing the specifications of the Synthetic Control Estimator and its properties).

so See Kousser et al., note 17, at 348-51. 
never enacted a tax limitation. These comparable states make up the "donor pool." The synthetic state is generated with the goal of minimizing the average distance between the composite created by the donor pool and the tax limitation state prior to the implementation of the measure. We then observe and compare the trajectory of both the tax limitation state and its synthetic control, constructing weights on the donor units so that the synthetic control and the tax limitation state are similar. ${ }^{51}$ That is, we compare the direction and size of the difference between the synthetic control state and the tax limitation state to determine the effect of the tax limitation itself.

The synthetic control itself is sensitive to the quality of the pre-implementation match. By assumption, the average distance between the synthetic control and the TL state should be zero. The worse the match is pre-implementation, the harder it is to make inferences about the effects of the measure. This is analogous to a DiD scenario where the pretest differences are always zero. Theoretically, if these pre-implementation differences are zero, then all unexplained variation in covariates across both time and space is perfectly captured by the model. This, can be vetted through pretest matching and proper donor pool construction. ${ }^{52}$ Also, the state being analyzed must be relatively comparable to states in the donor pool; otherwise the weights being proffered in the analysis are biased. Thus, again, attention needs to be paid to the specific construction of the donor pool.

TLs are passed through a variety of means. Some are driven by legislative fiat through referenda, some are passed by initiatives, and others are derived and voted on at constitutional conventions, as shown in Table 1 below. If all TELs were passed in a similar manner, then the counterfactual would be easily attainable. For example, had all TELs been passed in initiative states, it would be prudent to start with a donor pool of only initiative states, since that would be the applicable counterfactual. Because of the heterogeneous nature of how TELs are passed, we instead use a donor pool where the defining feature is the absence of a TEL, regardless of their other institutional structure.

As an inferential procedure, Abadie, Diamond, and Hainmueller recommend the use of "placebo tests." Placebo tests are exactly analogous to, and make the same assumptions as, classical Fisher randomization inference. ${ }^{53}$ This method is useful for generating infer-

51 The method uses actual observed values of a tax limitation ("treated") state and compares them directly to the values of a synthetic ("nontreated") state. This comparison provides the baseline for any estimators generated by the synthetic control analysis.

52 Abadie et al., note 15 , at 500 .

53 See generally Daniel E. Ho \& Kosuke Imai, Randomization Inference with Natural Experiments: An Analysis of Ballot Effects in the 2003 California Recall Election, 101 
ences on otherwise small samples that lack traditional statistical power, ${ }^{54}$ which makes this method attractive for analyzing state politics and policy. To perform this style of inference, we iteratively apply the synthetic control method to each state in the donor pool, which, in turn, generates a synthetic control case for each non-tax-limitation state in the donor pool as if it had a tax limitation applied to it. We then take the difference between each placebo state and its constructed control. These differences are assumed to be random: They could not conceivably be driven by the tax limitation implementation given their status as donor pool states so the likely explanation is that any difference displayed is due to exogenous economic, political, historical, or demographic factors. These differences are compared to the difference generated by comparing the actual tax-limitation state to its comparable synthetic control. This creates a distribution of differences that are then rank ordered to generate an exact $p$-value. ${ }^{55}$

TABLE 1

Tax Limitations

\begin{tabular}{lcll} 
State & $\begin{array}{c}\text { Year } \\
\text { Adopted }\end{array}$ & \multicolumn{1}{c}{ Type of Limit } & \multicolumn{1}{c}{$\begin{array}{c}\text { Method of } \\
\text { Enactment }\end{array}$} \\
Arizona & 1980 & Property Tax & Mixed \\
California & 1978 & Property Tax & Direct Initiative \\
Colorado & 1992 & General Revenue & Direct Initiative \\
Florida & 1995 & Property Tax & Convention \\
Idaho & 1978 & Property Tax & Mixed \\
Massachusetts & 1980 & Property Tax, & Direct Initiative \\
& 1986 & General Revenue & \\
Michigan & 1978 & General Revenue & Direct Initiative \\
Missouri & 1980 & General Revenue & Direct Initiative \\
& 1996 & & \\
Nevada & 1978 & Property Tax & Legislative \\
Oregon & 1978 & Property Tax & Direct Initiative \\
& 1991 & & ' \\
& 1996 & &
\end{tabular}

Am. J. Pol. Sci. 888, 890-93 (2006) (discussing and giving examples of randomization inference in a social science context).

54 Id. at 497.

55 These exact p-values are exactly the same as the p-values generated by Fisher randomization inference. See generally D.R. Cox \& N. Reid, A Theory of the Design of Experiments (2000).

56 We discuss four methods of enactment: (1) direct initiative, which indicates a measure drafted by voters that is then passed by a popular vote, (2) an indirect initiative, which indicates a measure drafted by the legislature that is then passed by a popular vote, (3) mixed, which indicates a measure that is an amalgam of both methods, (4) legislative, which indicates a legislatively-passed tax limitation or convention, which indicates that the measure is a constitutional amendment ratified by voters at a called constitutional convention. 
In order to better understand the effects of these tax limitations, we analyze their effects on three separate fiscal components: (1) total state and local own tax revenue, (2) total state and local expenditure, and (3) total state and local property taxes. Data used for this analysis runs from 1969-2000 and was collected from the Census Bureau's Survey of State and Local Government Finances. ${ }^{57}$ We balance on several covariates: lags of the dependent variable, population, per capita real income, and dummy variables for party control of each chamber of the state legislature and the governorship.

It is important to understand that tax limitations are all rate limitations rather than general fund limitations. Even if a state government is collecting taxes under the maximum level allowable under the budget constraint, a rate increase should see a reduction of taxes if no new taxes are created and there are no increases in population or income. Thus, controlling for total population and per capita income, we can infer that, ceteris paribus, we should not see an increase in tax collections. Therefore, our hypotheses are as follows:

H1: The passage of a tax limitations will, ceteris paribus, lead to a reduction in real total tax revenue per capita collected by the state.

H2: The passage of, specifically, a property tax limitation will, ceteris paribus, lead to a reduction in real property tax revenue per capita collected by the state. ${ }^{58}$

$H 1$ and $H 2$ should be fairly straightforward: These are primary effects of the imposed limitations. If we are to analyze the effectiveness of any tax limiting measure, it should first be effective at its stated goal of limiting taxes.

H3: The passage of, specifically, a property tax limitation will, ceteris paribus, lead to a reduction in real total tax revenue per capita collected by the state.

Although not as explicitly straightforward, the secondary effect described in $\mathrm{H3}$ should also be true. Many state governments collect property taxes as one of their primary sources of revenue. A reduc-

57 U.S. Census Bureau, Survey of State and Local Government Finances, http://www.cen sus.gov/govs/local/. Data, lab note and instruction, do-files, and detailed logged output are available at www.mccubbins.us or http://dvn.iq.harvard.edu/dvn/dv/mccubbins.

58 Although we consider property tax limitations to be tax limitations in general, it is important to highlight their specific differences for analysis of primary and secondary effects since the logic underlying specific limitations is slightly different than the logic underlying general limitations. 
tion in this revenue stream, thus, should lead to a reduction in the amount of tax revenue collected.

H4: The passage of a TL will, ceteris paribus, lead to a reduction in real property tax revenue per capita collected by the state.

This is even less explicit than $H 3$. The logic for the secondary effect of $\mathrm{H}^{4}$ is more circuitous but is based on the aforementioned fact that property tax is, often, the primary source of revenue collected by state governments. As such, a limitation in total tax collections would likely have ramifications for the amount of property taxes collected.

H5: The passage of any tax limitation (general or property specific) will, ceteris paribus, lead to a reduction in real expenditure per capita by the state.

H5 is what would be considered a tertiary effect of a tax limitation. All else equal, when revenue in a state decreases, the ability of the government to spend likewise should decrease.

To explore these hypotheses, in the next Part we present results from the synthetic control analysis. In doing so, we present the statistical results and then individually discuss some interesting cases.

\section{REsults}

The results of the synthetic control analysis are presented in Table 2 below. The results displayed include several important features:

- State name and fiscal component being analyzed: There are three components of interest: (1) total tax revenue, (2) expenditures, and (3) property taxes.

- Direction: This indicates the general trajectory of each fiscal component post-implementation of a tax limitation.

- MSPE ratio: This is the ratio of mean squared prediction error, calculated by taking the post-implementation prediction error and dividing it by the pre-implementation prediction error. In general, the higher this ratio is, the larger difference there is between the post-implementation state and its synthetic control. This typically will generate a higher p-value.

- Fischer exact p-value: This is calculated by rank ordering the MSPE ratios for the limitation state and all of the placebo states. A lower p-value indicates a higher likelihood of the result being a statistically unlikely result. This would indicate that we would be able to reject the null hypothesis that a tax limitation had no effect on the analyzed fiscal component. 
It is notable after looking at the results that only two out of the forty-two analyzed show any significance at the traditional 0.05 level. If we relax this to include the nontraditional 0.1 level, only three additional cases appear to be significant. Of these five, one actually shows a significant positive effect, so we can conclude that only four of the forty-two cases show any significant reduction in taxes, expenditures, or budgets.

\section{TABLE 2}

\section{Synthetic Control Results}

\begin{tabular}{|c|c|c|c|c|}
\hline State & $\begin{array}{l}\text { Fiscal } \\
\text { Component }\end{array}$ & Direction & MSPE Ratio & $\begin{array}{c}\text { Fischer Exact } \\
P \text {-Value }\end{array}$ \\
\hline \multirow[t]{3}{*}{ Arizona } & Tax Revenue & Negative & 10.305 & 0.23 \\
\hline & Expenditure & Negative & 10.304 & 0.1 \\
\hline & Property Tax & Negative & 16.587 & 0.47 \\
\hline \multirow{3}{*}{ California } & Tax Revenue & Negative & 24.689 & 0.33 \\
\hline & Expenditure & Negative & 30.498 & 0.29 \\
\hline & Property Tax & Negative & 10.368 & 0.71 \\
\hline \multirow[t]{3}{*}{ Colorado } & Tax Revenue & Negative & 1.609 & 0.33 \\
\hline & Expenditure & Negative & 1.519 & 0.71 \\
\hline & Property Tax & Negative & 0.152 & 1 \\
\hline \multirow{3}{*}{ Florida } & Tax Revenue & Positive & 0.432 & 0.76 \\
\hline & Expenditure & Positive & 0.824 & 0.76 \\
\hline & Property Tax & Positive & 2.836 & 0.52 \\
\hline \multirow{3}{*}{ Idaho } & Tax Revenue & Negative & 174.284 & $0.05 *$ \\
\hline & Expenditure & Negative & 37.334 & 0.29 \\
\hline & Property Tax & Negative & 16.518 & 0.62 \\
\hline \multirow{3}{*}{$\begin{array}{l}\text { Massachusetts } \\
\text { (1980) }\end{array}$} & Tax Revenue & Negative & 10.852 & 0.29 \\
\hline & Expenditure & Negative & 8.283 & 0.57 \\
\hline & Property Tax & Negative & 4.156 & 0.90 \\
\hline \multirow{3}{*}{$\begin{array}{l}\text { Massachusetts } \\
\text { (1986) }\end{array}$} & Tax Revenue & Positive & 2.491 & 0.43 \\
\hline & Expenditure & Positive & 3.636 & 0.57 \\
\hline & Property Tax & Negative & 3.573 & 0.86 \\
\hline \multirow[t]{3}{*}{ Michigan } & Tax Revenue & Negative & 55.957 & 0.19 \\
\hline & Expenditure & Negative & 5.796 & 0.81 \\
\hline & Property Tax & Negative & 255.668 & 0.14 \\
\hline Missouri & Tax Revenue & Negative & 1.358 & 1.00 \\
\hline \multirow{2}{*}{ (1980) } & Expenditure & Negative & 3.836 & 0.86 \\
\hline & Property Tax & Negative & 27.288 & 0.43 \\
\hline \multirow{3}{*}{$\begin{array}{l}\text { Missouri } \\
\text { (1996) }\end{array}$} & Tax Revenue & Positive & 2.133 & 0.29 \\
\hline & Expenditure & Negative & 0.243 & 0.76 \\
\hline & Property Tax & Negative & 0.993 & 0.86 \\
\hline \multirow[t]{3}{*}{ Nevada } & Tax Revenue & Negative & 56.145 & 0.19 \\
\hline & Expenditure & Negative & 56.977 & 0.29 \\
\hline & Property Tax & Negative & 208.841 & 0.14 \\
\hline & Tax Revenue & Negative & 92.176 & 0.19 \\
\hline \multirow{2}{*}{ (1978) } & Expenditure & Positive & 7.397 & 0.71 \\
\hline & Property Tax & Negative & 33.054 & 0.33 \\
\hline \multirow{3}{*}{$\begin{array}{l}\text { Oregon } \\
\text { (1991) }\end{array}$} & Tax Revenue & Negative & 0.228 & 0.86 \\
\hline & Expenditure & Positive & 9.743 & 0.14 \\
\hline & Property Tax & Negative & 68.897 & 0.1 \\
\hline \multirow{3}{*}{$\begin{array}{l}\text { Oregon } \\
\text { (1996) }\end{array}$} & Tax Revenue & Negative & 0.330 & 0.71 \\
\hline & Expenditure & Positive & 7.19 & 0.10 \\
\hline & Property Tax & Negative & 10.963 & $0.05^{*}$ \\
\hline
\end{tabular}


We turn now to some of the more interesting results from the table. Here, we first analyze two of the typical examples for successful tax limitations: TABOR from Colorado and Proposition 13 from California. We then discuss some of the statistically significant results. ${ }^{59}$

\section{A. Colorado: Taxpayer's Bill of Rights}

Colorado's 1992 Taxpayer's Bill of Rights has been examined time and again for its apparent strictness. TABOR has the following provisions: (1) Growth in total own-source revenues and spending in Colorado are tied to the sum of percent population growth and percent increase in inflation. ${ }^{60}$ The intention was to limit inflation-adjusted per capita revenue and spending. Collections of revenue over this limit were to be reimbursed to taxpayers. (2) Increases in tax rates or outright new taxes require voter approval. ${ }^{61}$

TABOR, however sought to be much more stringent a measure. Kousser, McCubbins, and Moule describe what we would expect from TABOR:

[Colorado's TABOR] initiative has many of the characteristics that prior research would suggest are necessary to ensure its success. This constitutional amendment limits all taxes and revenues at the state and local level and requires voter approval for any tax increases or to change TABOR itself. These provisions mean that TABOR is quite strict in the letter of its law. ${ }^{62}$

In an epilogue to the TABOR story, the authors note that by 2005 , the "anticipated cuts under TABOR were so severe that Colorado's Republican Governor Bill Owens . . backed a drive to call a five-year 'Timeout for TABOR'."63 Thus, the success of the initiative was its own undoing, so to speak. The government, almost ironically, backed an initiative, Proposition C, that was voted on to suspend TABOR. ${ }^{64}$

To this end, Figure 1 below shows expenditures in Colorado in comparison to its synthetic control.

59 Although one of Oregon's measures is reported as statistically significant, there does not appear to be enough data post-implementation in either case to warrant discussion as there is simply not enough data to make judgments. Figures for these measures (as well as all other nonsignificant measures), both for synthetic control comparison and the placebo tests are posted in the online appendix.

60 Colo. Const. art. X, $\S 20$, cl. 7-8.

61 Colo. Const. art. X, $\$ 20$, cl. 3 .

62 Kousser et al., note 17 , at 352 .

63 Id. at 354 (citation omitted).

64 Id. at 354. 
FIGURE $1^{65}$

Total Expenditures

Colorado vs. Synthetic Control

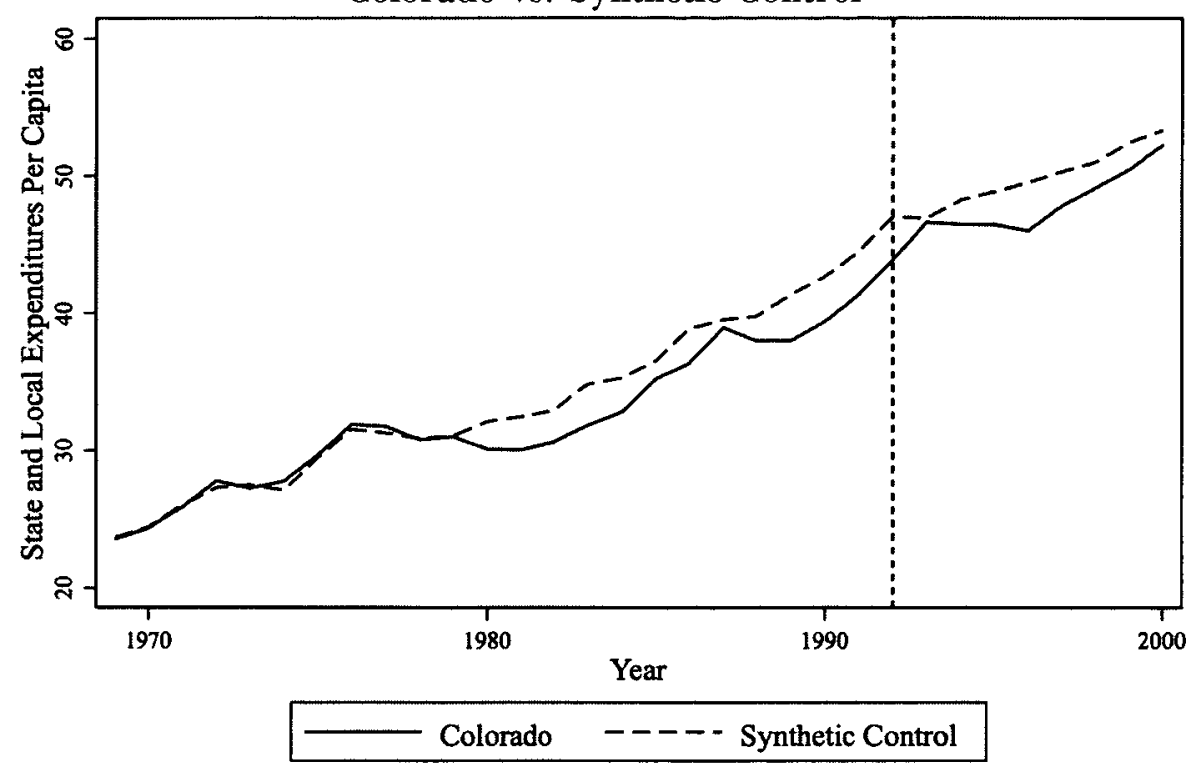

There are several things to note about this figure. First, there appears to be a deviation between Colorado and its synthetic control starting in 1979, long before the implementation of the TABOR amendment. Total state and local expenditures in Colorado remain lower than the constructed synthetic control for the entire period from 1979 to 1992 . This difference remains nearly constant for the post-taxlimitation period. Second, because this difference does not seem to increase over time, it is difficult to conclude that TABOR had a significant effect on Colorado's expenditures. Indeed, the placebo test analysis, shown in Figure 2 below, corroborates this null result.

65 Data from U.S. Census Bureau, note 57. 


\section{Figure 2}

\section{Colorado}

Placebo Test-Expenditure

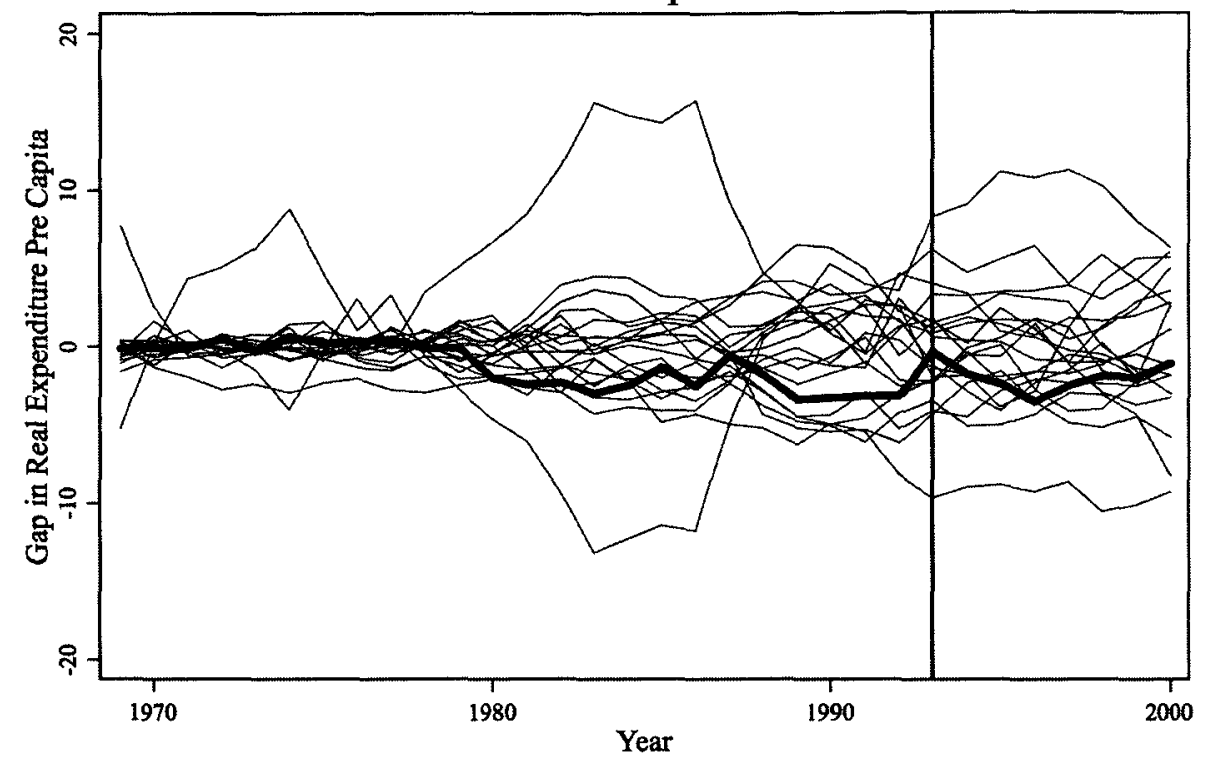

Note: Colorado's expenditure trajectory is highlighted in bold.

Despite the fact that actual real per capita expenditures in Colorado have been declining since the late 1970's, the path of expenditures is almost directly in the middle of the placebo states. The resulting Fisher exact p-value is 0.71 .

We turn now to an analysis of total own-source state and local tax revenue in Colorado as displayed in Figures 3 and 4 below. 
FigURE $3^{66}$

Total Tax Revenue

Colorado vs. Synthetic Control

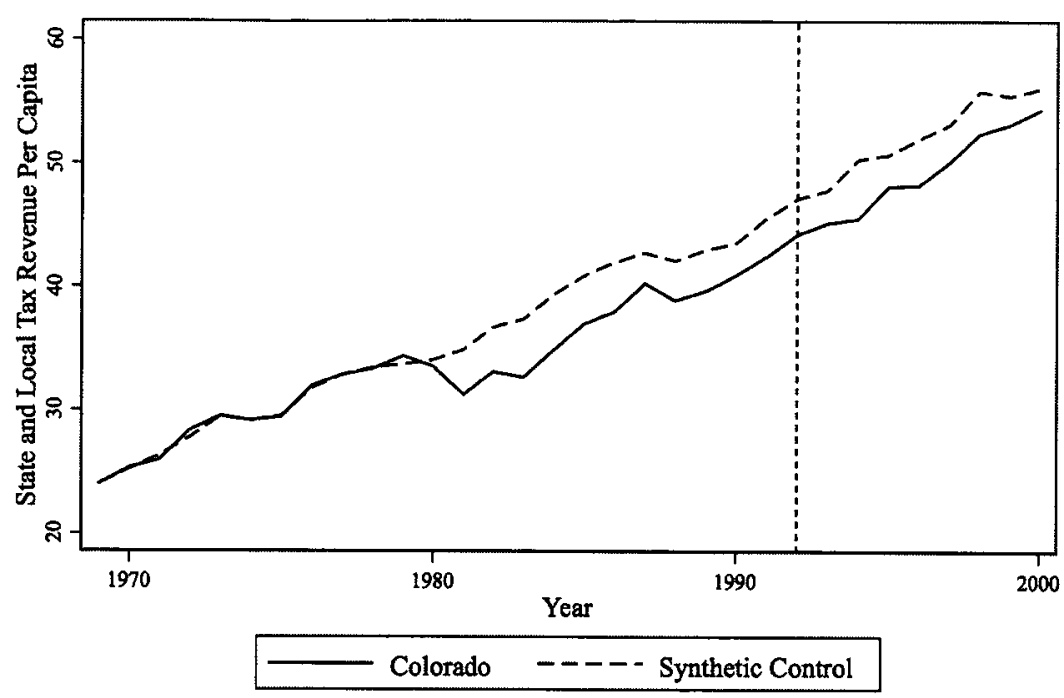

Figure $4^{67}$

Colorado

Placebo Test-Total Tax Revenue

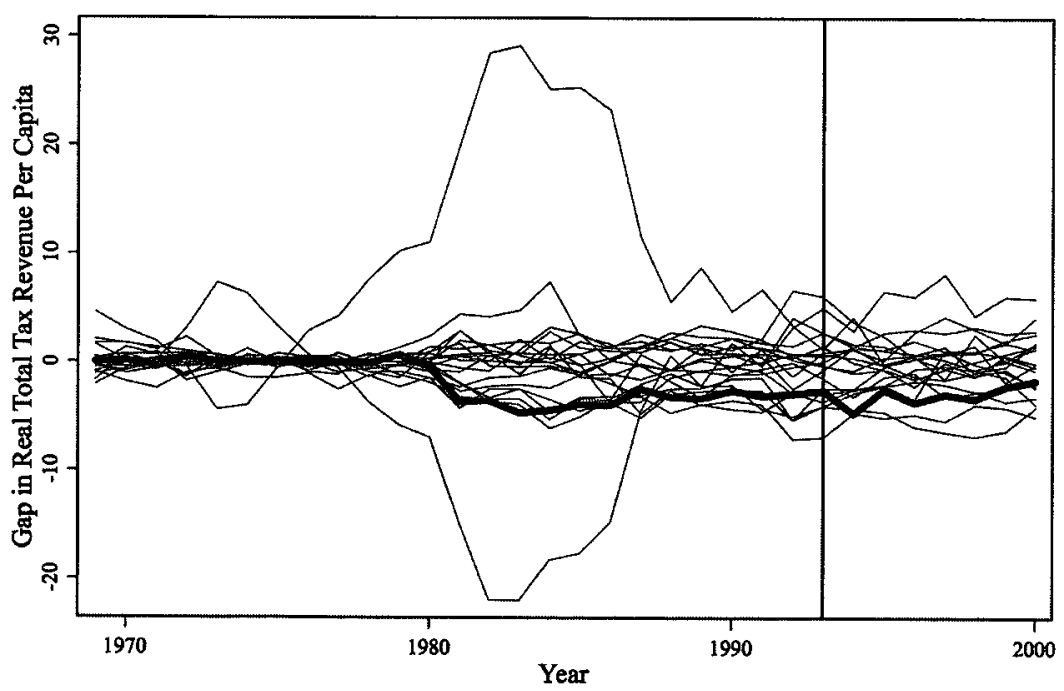

Note: Colorado's tax revenue trajectory is highlighted in bold.
66 Id.
$67 \mathrm{Id}$. 
Colorado's own-source state and local revenue trajectory seems to be near the estimated counterfactual outcomes for states, which is reflected in the lower p-value of 0.33 . The evidence, however, does not lead us to conclude that TABOR, in and of itself, had an effect on own-source state and local revenue. It is especially noteworthy to see that the biggest change in own-source revenue was again in the late 1970 's. These results run counter to the typical story told about TABOR.

\section{B. California: Proposition 13}

In the late 1970's, California was mired in a deep recession that was mixed, ironically, with a decade-long period of inflation, especially in real estate prices. This led, eventually, to a "tax revolt" and the passage of the landmark Proposition 13 in 1978,68 which limited ad valorem property taxes and Proposition 4 (the Gann Initiative) in $1979,{ }^{69}$ which was an expenditure limitation. ${ }^{70}$ Proposition 13 had the following provisions:

- Property taxes limited to $1 \%$ of assessed value of property. ${ }^{71}$

- Valuations of property were rolled back to fiscal year 1976 levels and growth in assessed value was capped at a maximum of $2 \%$ per year. ${ }^{72}$

- Property is now only reassessed upon transfer. ${ }^{73}$

- Any further tax increases require a supermajority of votes in the legislature. ${ }^{74}$

- Local tax increases need to be specified and require supermajority consent of voters to pass. ${ }^{75}$

Proposition 13 and the Gann Initiative were wildly popular, with Proposition 13, for example, garnering almost two-thirds of the popular vote. ${ }^{76}$ Looking back, it is easy to see why this tax revolt occurred. In the years leading up to the passage of Proposition 13, California's property taxes were tremendously high. As shown in Figure 5 below,

68 Cal. Const. art. XIII A.

69 Cal. Const. art. XIII B.

70 Because these two landmark initiatives were passed within a year of each other, it is impossible to disentangle the effects of one or the other alone. This makes teasing out the actual causal effects of either of these policies by itself impossible. As such, the analysis presented in this Section is representative of the cumulative effects of both of these policies.

71 Cal. Const. art. XIII A, \& 1(a).

72 Id. $\S 2$ (a)-(b).

73 Id. $\S 2(a)$.

74 Id. $\S 3(a)$.

75 Id. $\S 4$.

76 Jack Citrin, Introduction to Paul Richter, California and the American Tax Revolt: Proposition 13 Five Years Later 1, 7 (Terry Schwadron ed., 1984). 
in some years California's real property taxes per capita were more than twice the national average and in many years it was nearly so.

\section{FIGURE $5^{77}$}

Property Taxes

California vs. National Average

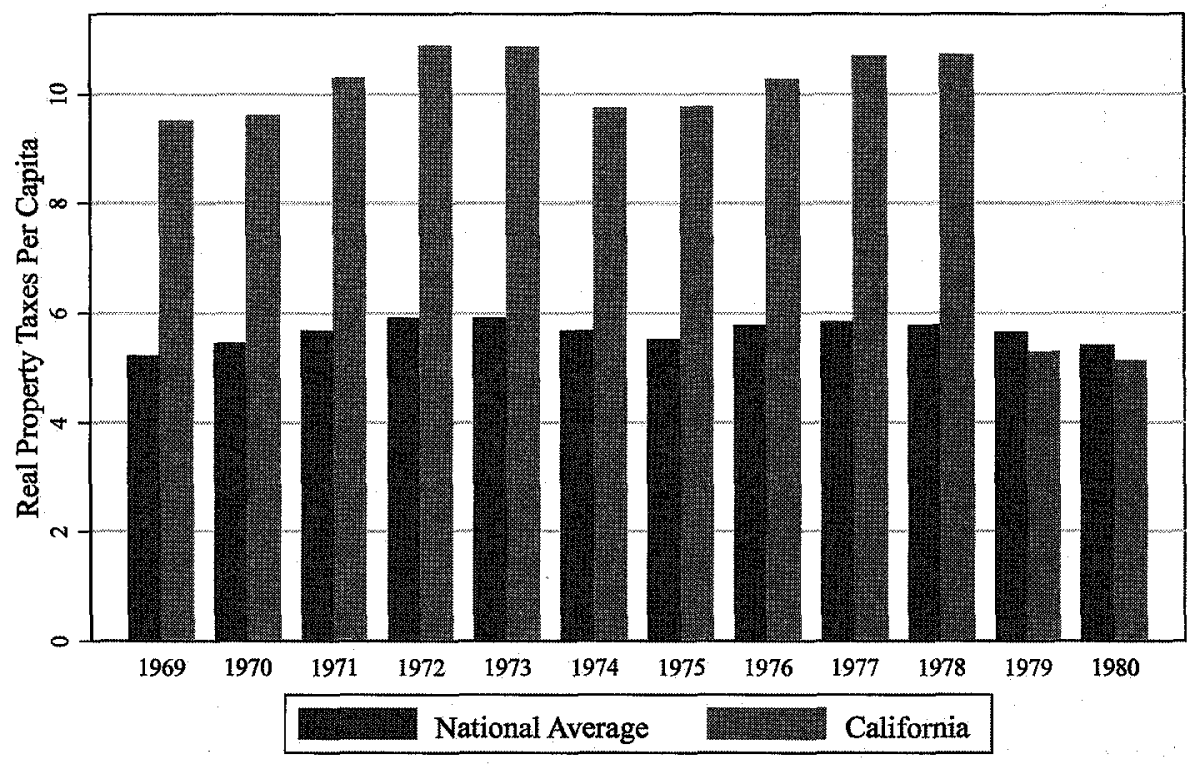

Note: Real property taxes per capita are multiplied by $1 \times 10^{6}$ for purposes of legibility. The national average does not include California.

Figure 5 is notable for two reasons. First, as mentioned previously, California had very high per capita property taxes, in some years almost doubling the national average. California leaned heavily on these taxes, constantly reassessing property values to squeeze as much value as they could out of the swiftly increasing housing market. Second, after the passage of Proposition 13, it is apparent that collected property taxes fell to just below the national average. Proposition 13 seems to have had a tremendous effect on property taxes. Comparing the actual time series on real property taxes per capita in California to its synthetic counterfactual, as shown in Figure 6 below, corroborates this effect.

77 Data from U.S. Census Bureau, note 57. 
Figure $6^{78}$

Property Taxes

California vs. Synthetic Control

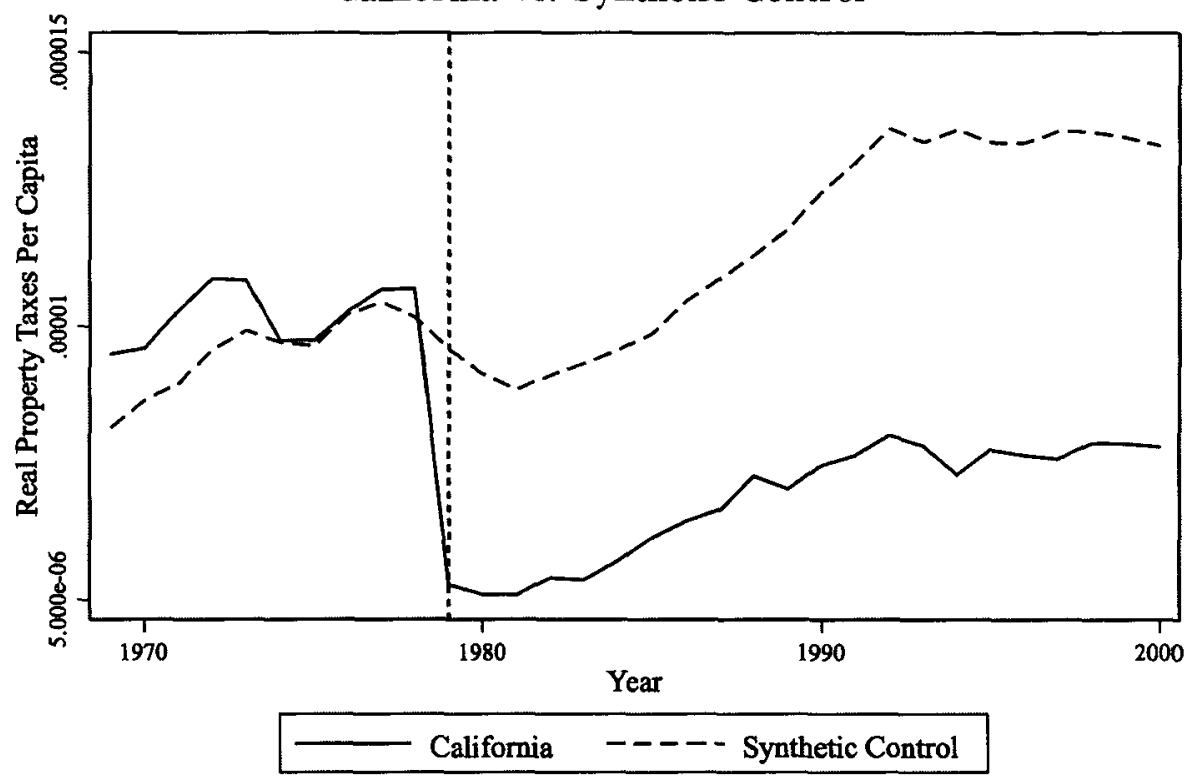

Just as Figure 5 would indicate, there is a precipitous drop in property tax collections starting in 1979. Afterwards, the level of real per capita property taxes stays at the same low level after the enactment of the tax limitations, even when compared to the placebo tracks for states in the donor pool. This is mirrored in the placebo test for property taxes, shown in Figure 7. 
Figure 7

California

Placebo Test-Property Tax

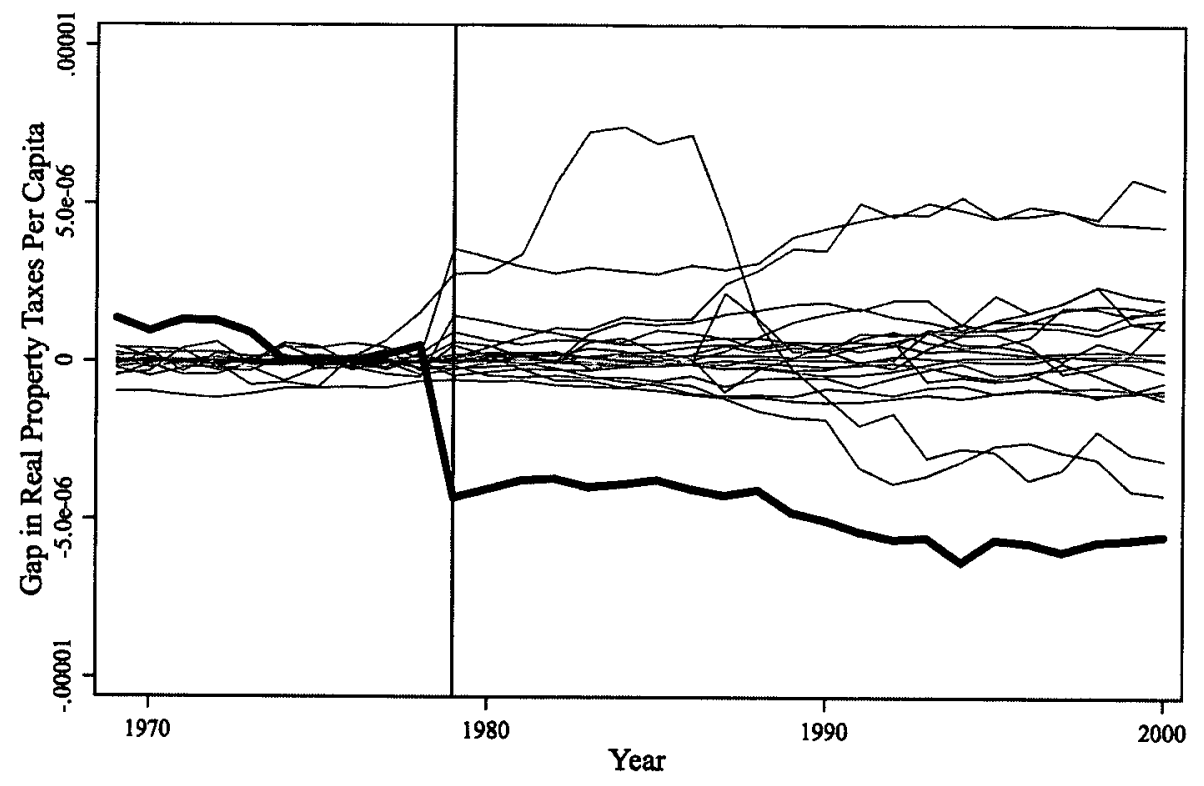

Note: California's property tax trajectory is highlighted in bold.

In constructing a test, however, there is enough variation, specifically in a positive direction, such that the low trajectory shown by the California outcome is not sufficiently atypical. The variation actually appears quite wide. Thus, we cannot make any ultimately conclusive statement about the effect of Proposition 13 on California's property taxes.

It is, however, probable that there may be some issues with modeling property taxes. Property taxes provide "bad" matches pretest using the synthetic control method, meaning that pretest synthetic controls are usually substantially farther away from the actual state outcomes to which they are being compared. As such, the denominators in our statistics are quite large. It is even notable in Figure 6. In this Article, we have used a single model to estimate own-source state and local revenue, state and local expenditures, and other budget variables. Some of the covariates used to perform this analysis do not perform very well in estimating state and local property taxes. The biggest problem is related to the first and last axiom of real estate: location, location, location. We eschew local-based models of property taxes and our estimates suffer accordingly. For example, housing prices could be increasing in the San Francisco Bay Area while simultaneously decreasing in the Rocky Mountain Plateau. This makes it 
harder for the synthetic matching method to match on unobserved exogenous shocks to property taxes. As such, a more theoretically robust model of property taxation may be needed before this effect can be explored precisely. It is also likely that California's level of fiscal inputs is drastically larger than almost every other state in the nation, barring possibly New York. As a result, it is likely very difficult to find an accurate statistical match for California. Within the synthetic control method, this generally would make the results more unreliable than others. It certainly appears that California's level of property taxation is drastically lower than any of the other placebo states, despite the results of the test itself.

California also sees dips in revenue and expenditure, though, again in our placebo tests, neither of these decreases is significant. Figure 8 shows California's total tax revenue in comparison to its synthetic control. Figure 9 shows the placebo test for total tax revenue. These figures both mimic the change in property tax revenue, likely due to the fact that property taxes make up a large part of the revenue collected by the California state government.

Figure $8^{79}$

Total Tax Revenue

California vs. Synthetic Control

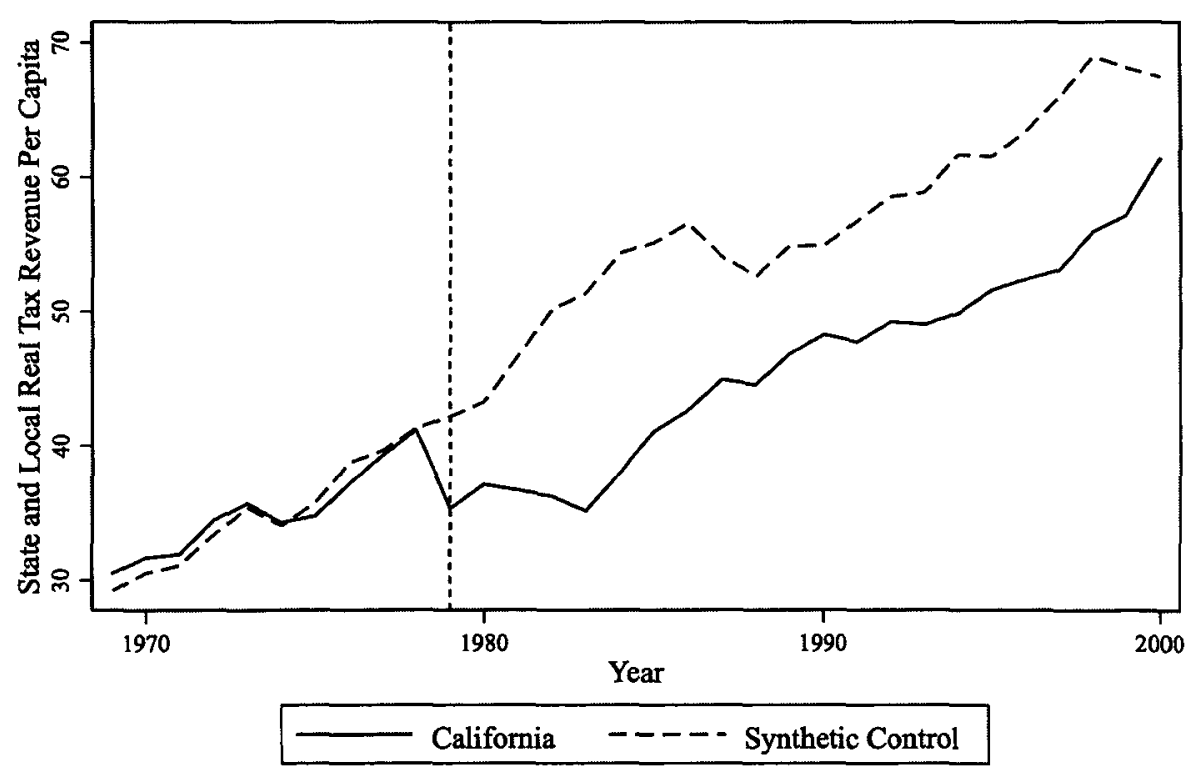

${ }^{79}$ Id. 


\section{Figure 9}

California

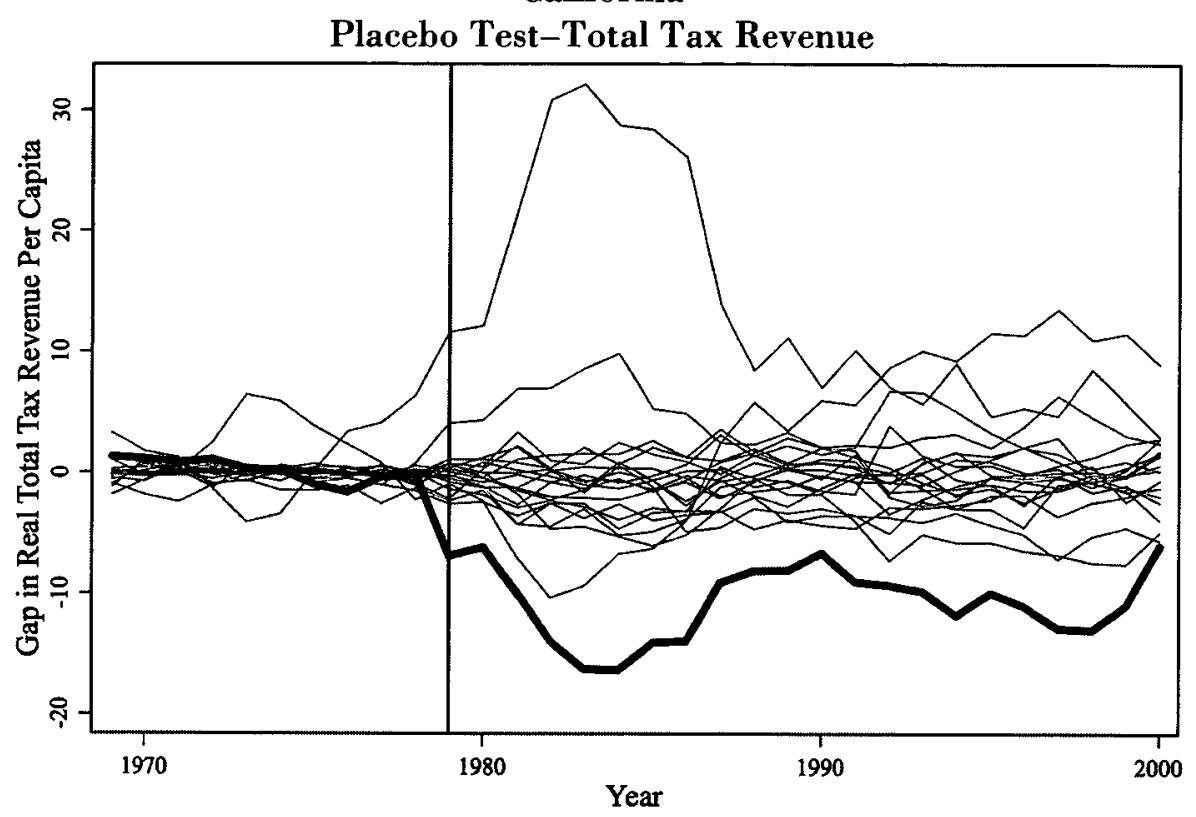

Note: California's tax revenue trajectory is highlighted in bold.

As a tertiary effect, we might expect that expenditures would fall in California given that one of its primary sources of revenue was capped, followed soon after by an expenditure limitation. Figures 10 and 11 show the comparison of actual tax-limitation-treated expenditure and its synthetic control figure and the placebo test for donorpool cases respectively for expenditures in California.

The effect of Proposition 13 is much less pronounced on real per capita state and local expenditure than it is for the revenue streams discussed above. 
Figure $10^{80}$

Expenditures

California vs. Synthetic Control

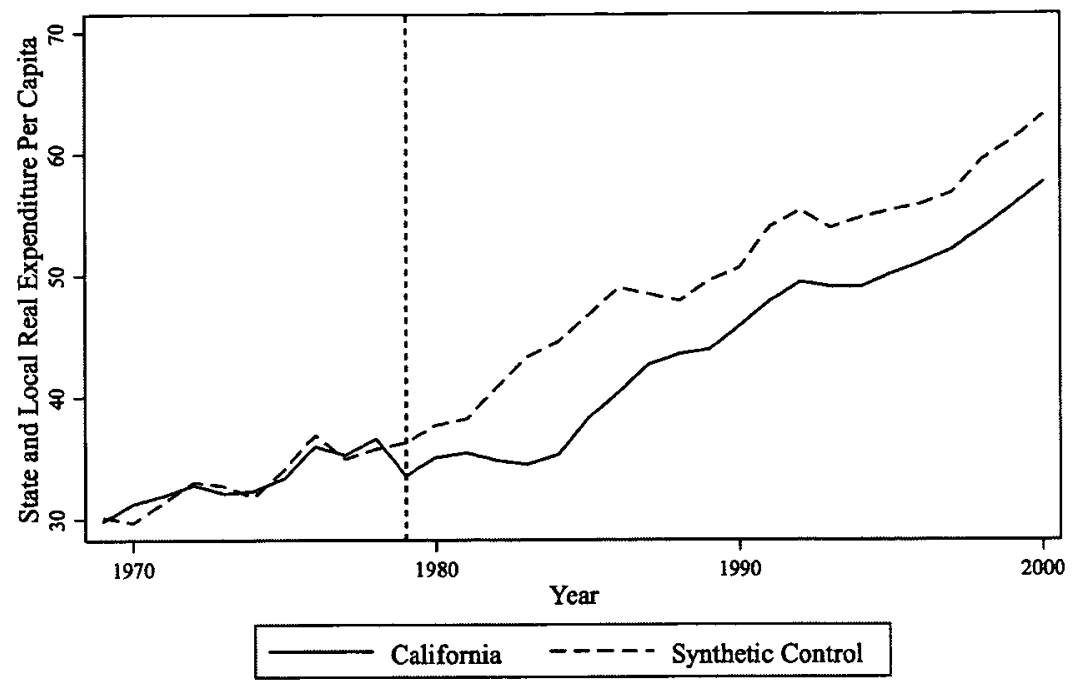

FIGURE $11^{81}$

California

Placebo Test-Expenditure

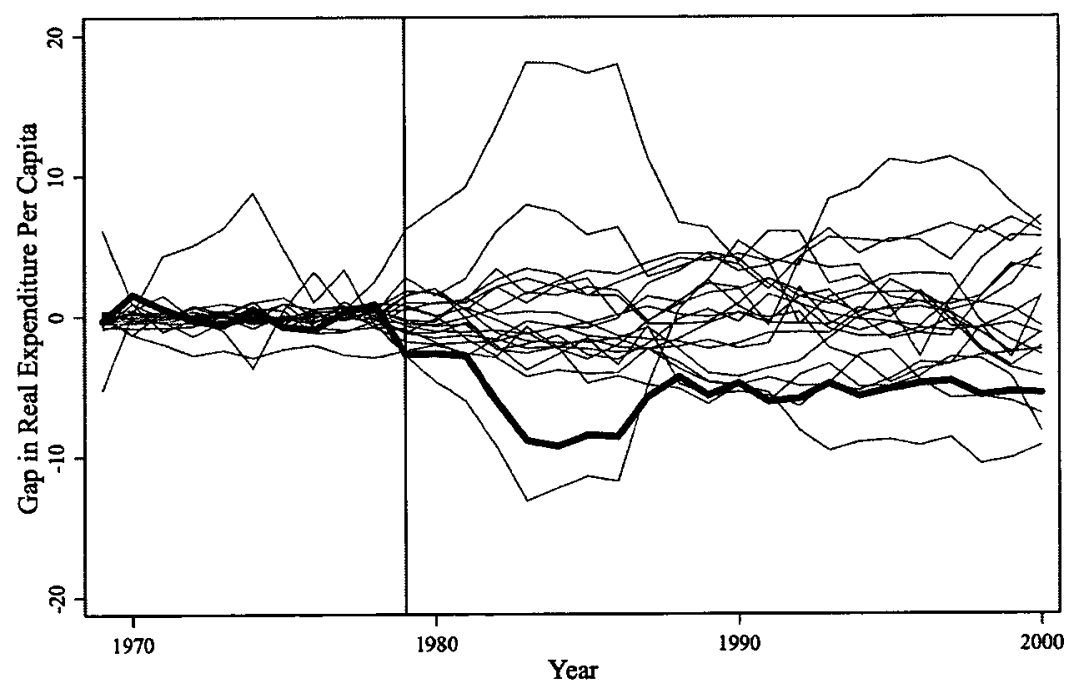

Note: California's expenditure trajectory is highlighted in bold.

80 Id.

81 Id. 
It is notable that Proposition 13, on its face, looks like it had substantial effects despite the fact that none of the placebo tests indicate a significant p-value. Changes in California's fiscal policy do exhibit strong directional effects, however, that are quite indicative of success. It is notable that California passed several high profile initiatives in a row that both sought to limit taxes and expenditures. Because they were passed in such rapid succession, it is impossible to actually parse the effects of each measure. As such, we can only test their interaction, even using a technique as powerful as the synthetic control method.

It is well known that state and local governments in California have long battled Proposition $13,{ }^{82}$ which is further indicative of an effect. These battles, however, highlight the government's ability to circumvent the measure by shifting the revenue burden onto other, nontax sources, such as charges and fees, ${ }^{83}$ municipal assessment districts, ${ }^{84}$ or even other tax sources, such as sales taxes. ${ }^{85}$

\section{Nevada: Question 6 and Legislative Response}

Nevada's case is unique in our sample as it is the only example of a legislative measure pre-empting an initiative. It is required in Nevada that ballot measures are voted on twice before they are permanently in effect; the second vote is held two years after the first. ${ }^{86}$ This gives the legislature a unique opportunity to respond to these ballot measures that is not afforded in other states. This is exactly the case with Nevada's tax limitation implementation.

Nevada has had a property tax limit in place since 1936 that limited property tax rates to $5 \%$ of assessed value. ${ }^{87}$ California's Proposition 13 had set off a wave of indignation about the level of property taxes in particular. Nevada was one of the thirty states to consider a tax limitation after Proposition 13. Of those thirty measures, thirteen were successful. Voters in Nevada placed their version of Proposition 13, Question 6, up for vote in the November general election. ${ }^{88}$ Ques-

82 See McCubbins \& McCubbins, note 48.

83 Kousser et al., note 17 , at 351 .

84 Kogan \& McCubbins, note 5, at 7-10.

85 McCubbins \& McCubbins, note 48, at 19-20; Jonathan Schwartz, Prisoners of Proposition 13: Sales Taxes, Property Taxes, and the Fiscalization of Municipal Land Use Decisions, 71 S. Cal. L. Rev. 183, 184 (1997).

86 Nev. Const. art. XIX, $\$ 2$.

87 Id. art. X, § 2.

88 State of Nevada, Dep't of State, Constitutional Amendments to Be Voted upon in State of Nevada at General Election, Nov. 7, 1978 (1978), available at http:/www.leg.state. nv.us/Division/Research/VoteNV/BallotQuestions/1978.pdf. 
tion 6 had several key provisions that were all but identical to provisions in Proposition 13:

- It lowered the property tax rate to $1 \%$ of assessed value.

- Assessed valuations were rolled back to fiscal year 1976 levels and further limited increases in these valuations to $2 \%$ per year to account for inflation.

- Required a supermajority vote of the legislature to raise state taxes.

- Similar provisions were applied to local taxation. Local tax increases, however, would require a supermajority approval of the voters.

This bill, like Proposition 13, is remarkable in its stringency and in 1978 it passed with $78 \%$ of the popular vote. ${ }^{89}$ In order to be placed in the constitution, however, it needed to be voted on again in 1980. It comes as no surprise, then, that in response to this measure, the state legislature twice lowered the property tax rate. The first lowering was in 1979 , which lowered the effective property tax rate to $1.1 \%$ and the last of was in 1981, which lowered the aforementioned rate again to approximately $0.6 \% .^{90}$ These legislative responses were well received and Question 6's second round of voting in 1980 saw its defeat, as it only received $42 \%$ of the vote. ${ }^{91}$

Thus, we have a clear story in Nevada of the legislature pre-empting the passage of a seemingly strict initiative and reason to more exhaustively analyze the compounding effects of various tax limitations passed in the window following 1978. To examine the results of this battle between the legislature and the voters on property taxes, see Figure 12 below.

89 Nevada Legislative Counsel Bureau, Background Paper 83-7, Nevada Tax Relief: 1978-1983, at 2 (1983), available at http://www.leg.state.nv.us/Division/Research/Publica tions/Bkground/BP83-07.pdf.

90 Id. at 2.

91 Id. at 3. 
FIGURE $12^{92}$

Property Tax

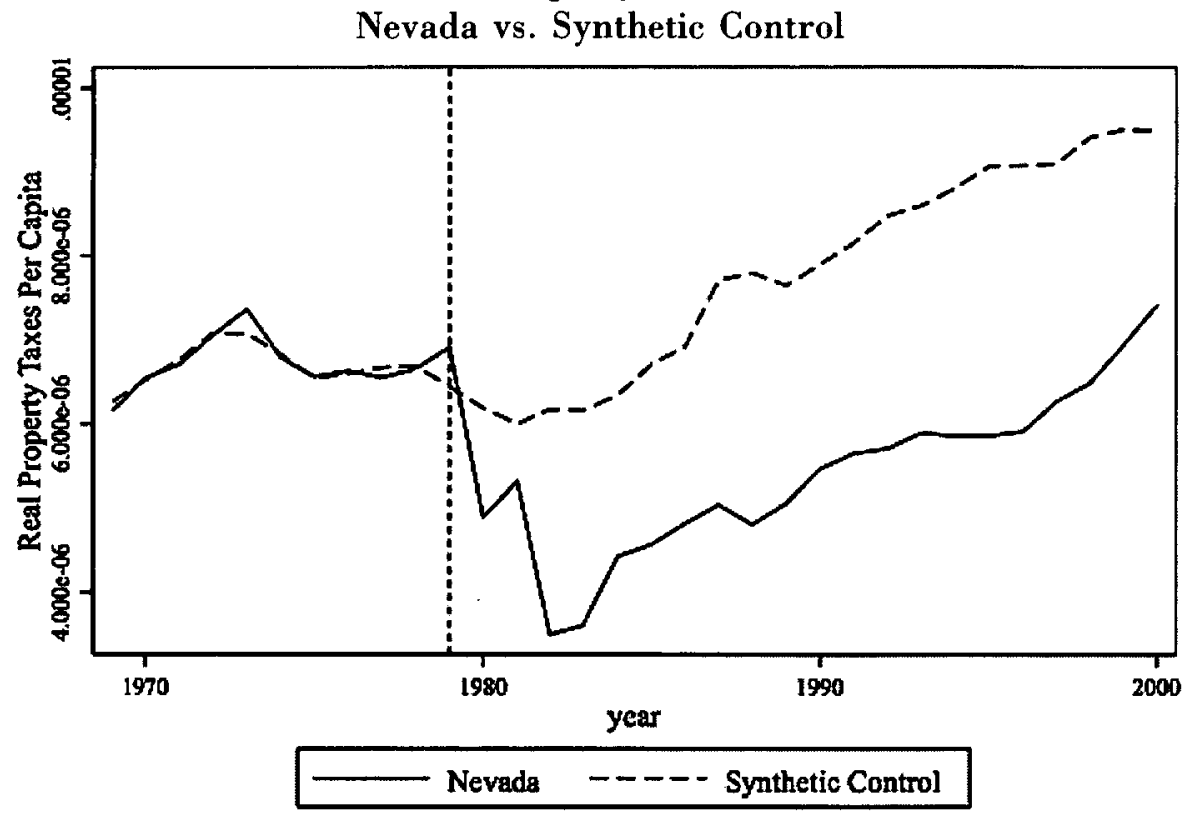

Post implementation Nevada sees a marked drop in real state and local property taxes per capita while its corresponding synthetic control stays roughly steady. The reduction in collected taxes is highlighted by two smaller drops, one that seems to correspond to each legislative measure passed in the wake of Question 6's first vote. After this drop, Nevada and its synthetic control increase in almost lockstep with one another. The placebo test for property taxes in Nevada is shown in Figure 13.

92 Data from U.S. Census Bureau, note 57. 
Figure 13

Nevada

Placebo Test-Property Tax

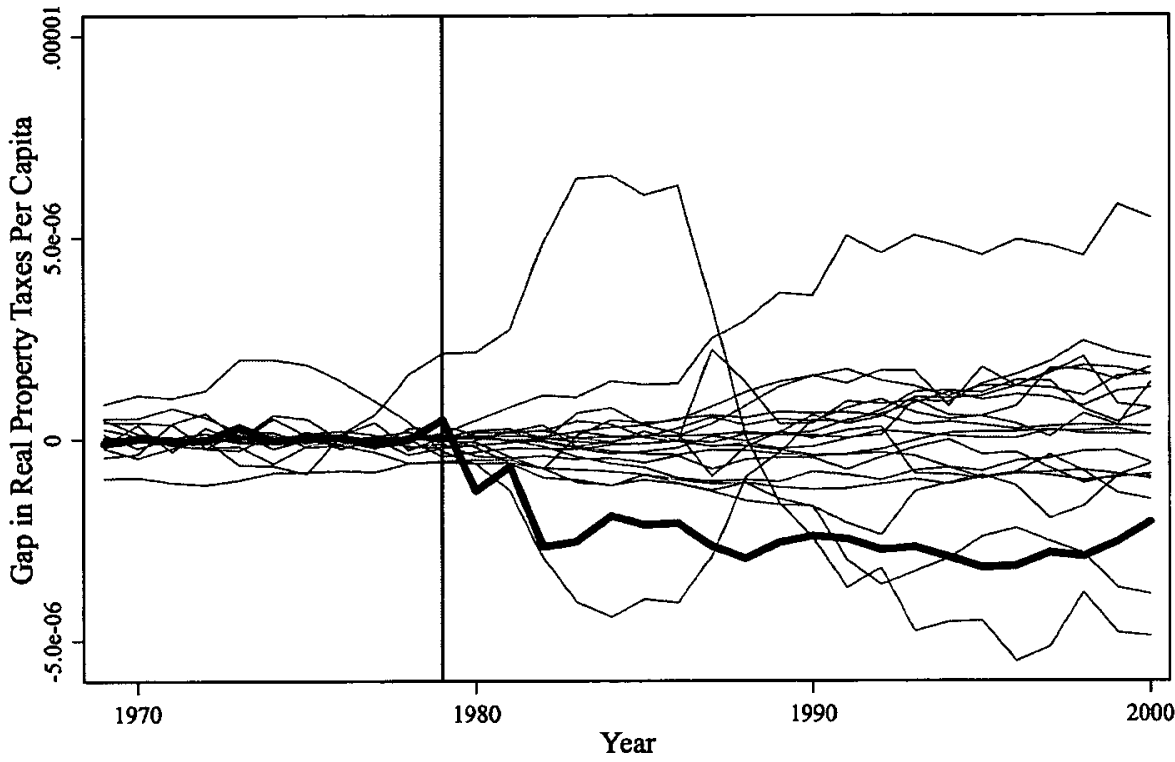

Note: Nevada's property tax trajectory is highlighted in bold.

Nevada's trajectory, although not the lowest, is marked by its consistency. However, there is no associated statistical significance with this placebo test. Other states that have higher negative gaps at the end of the time series have much larger positive gaps right around the implementation period. This, however, might just be due to the aforementioned matching errors that would be associated with property taxes. Looking only at the expected primary effect of Question 6 and its subsequent pre-emptive legislative measures, there appears to be little substantial effect. Yet, there appears to be a large effect on total tax revenue, as demonstrated in Figures 13 and 14 below. 
FIGURE $14^{93}$

Total Tax Revenue

Nevada vs. Synthetic Control

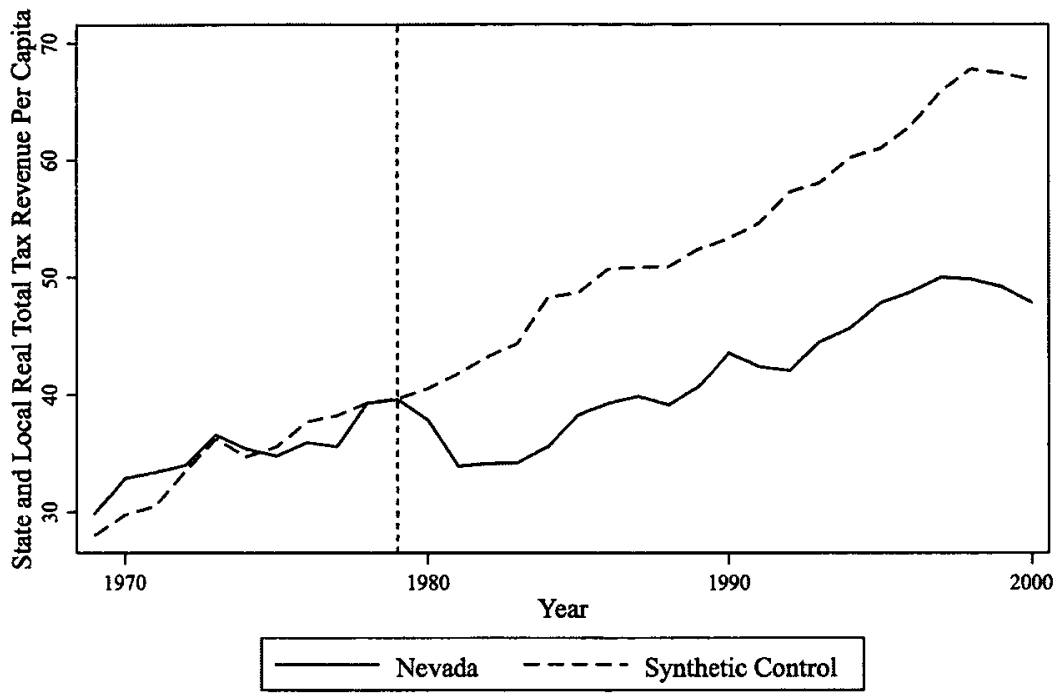

Figure 15

Nevada

Placebo Test-Total Tax Revenue

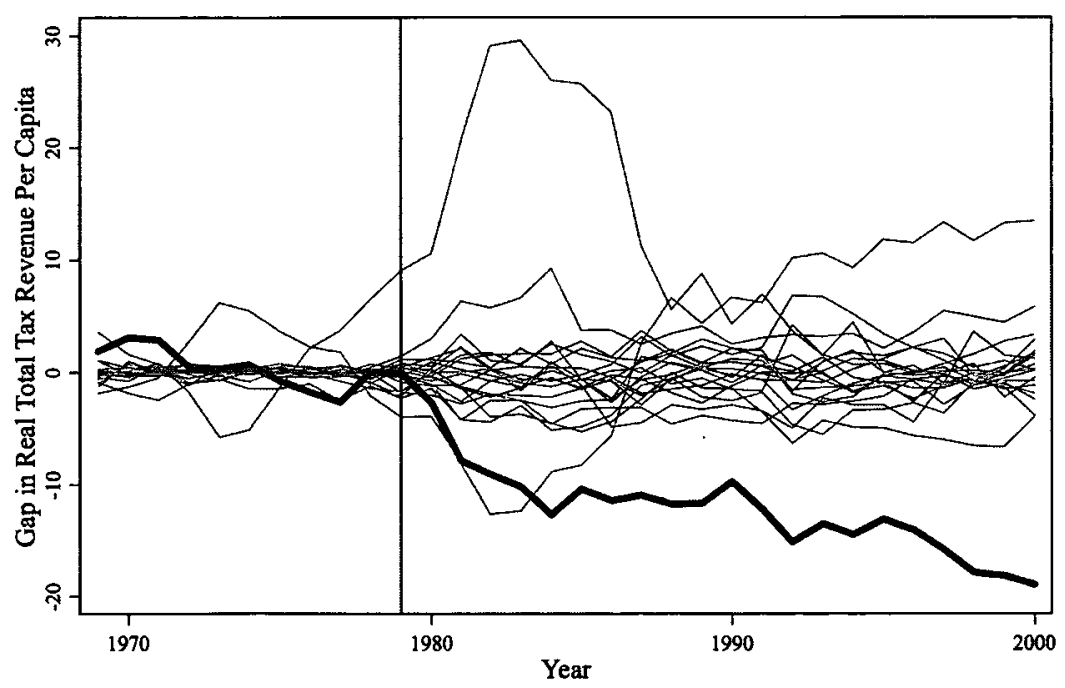

Note: Nevada's tax revenue trajectory is highlighted in bold.

93 Id. 
Nevada sees a drop in revenue post implementation in comparison to its synthetic control. Unlike real state and local property taxes per capita, though, the difference between Nevada and its synthetic control for real total own-source tax revenue per capita increases over time. This is clearly shown in the placebo graph, where it seems to be clear that Nevada has the largest post-treatment gap. However, this result is not statistically significant. This is, however, likely due to the nature of the synthetic control analysis. Nevada has, by far, the largest negative post-treatment gap and the second largest post-treatment gap in general (to Wyoming, which is positive). The two states that have larger MSPE ratios have average pre-implementation differences of below one, while the post-test prediction errors are at least eight times less than the gap seen in Nevada. It is likely that the placebo test is skewed because of these near perfect matches and that the results are an artifact of the measurement technique. As such, it is likely that there is an effect in Nevada of the legislative pre-emption of Question 6. This is mostly corroborated by Figure 15, which shows a placebo test for expenditures.

\section{FiguRE $16^{94}$}

Nevada

Placebo Test-Expenditure

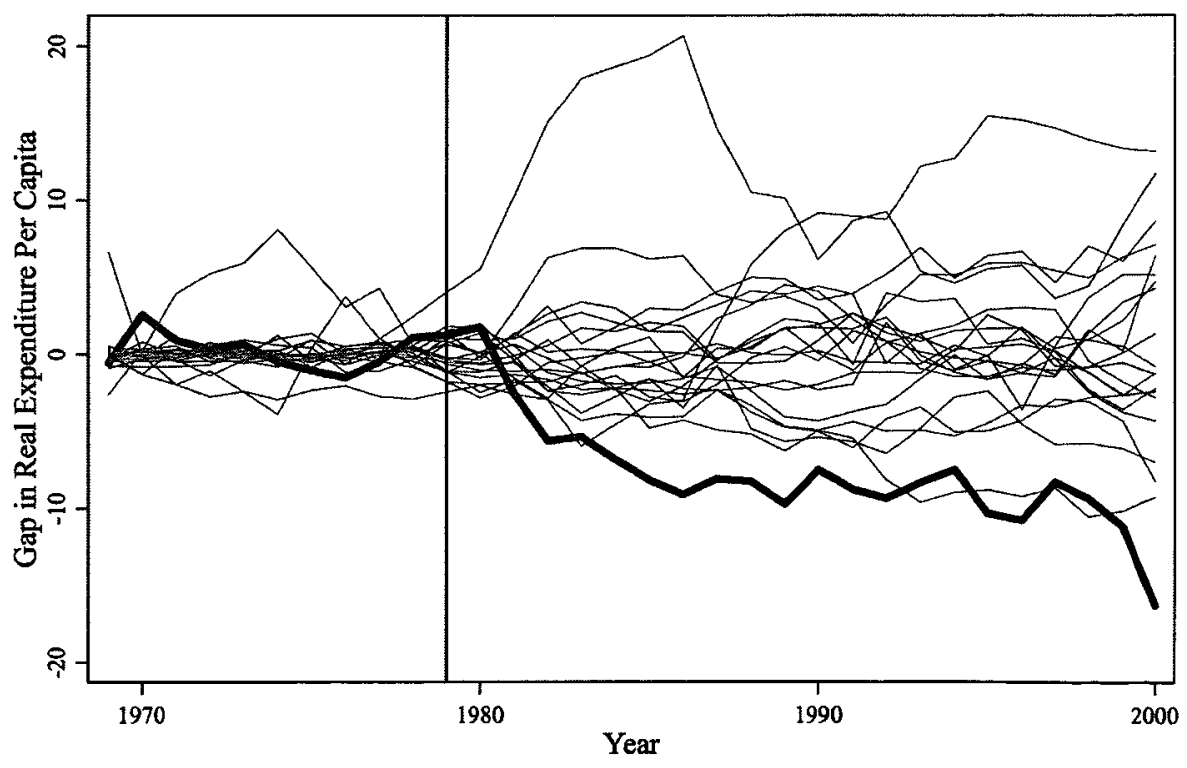

Note: Nevada's expenditure trajectory is highlighted in bold.

94 Id. 
Here, while Nevada still has a larger negative gap (relative to the zero or "no change" line) than other placebo states, the effect is not nearly as pronounced as it was in California. Statistical significance eludes again. Instead, it appears to fall within the bounds of the distribution of other placebo states and we cannot reject the null hypothesis that there was no effect on expenditure levels. Nevada also saw a tax and expenditure limitation passed in 1979 that was targeted at state spending levels ${ }^{95}$ followed later in 1996 by the implementation of term limits. ${ }^{96}$ It is difficult to disentangle these effects especially when several policies with large fiscal implications were being passed almost simultaneously.

Yet, Nevada's case is still worthy of exploration given the tax limitation's unique path to implementation. It is, indeed, possible that the legislature wrote a bill that provided citizens with property tax relief while simultaneously providing relaxed limitations in keeping with legislative incentives. It is also possible that the political environment became more conducive to the implementation of these measures. Further, there is a possibility that Nevada's cavalcade of policy interactions around this time period was more effective at limiting legislative budget action than any one measure was by itself. Despite our nonsignificant findings, further study is warranted.

\section{Idaho: The 1\% Solution}

Like Nevada, Idaho voters passed a direct statutory initiative identical to California's Proposition 13 in November of 1978.97 This left the legislature free to manipulate and amend the initiative, which they did numerous times in the following years. ${ }^{98}$ To analyze the primary effects of this property tax limitation, see Figure 16, which shows Idaho property taxes and its synthetic control.

95 Nevada Legislative Council Bureau, note 89, at 5-6.

96 Elections Division, State of Nevada, Ballot Questions 1996, Question No. 9 (1996), available at http://www.leg.state.nv.us/Division/Research/VoteNV/BallotQuestions/1996 .pdf.

97 Idaho St. Tax Comm'n, Property Tax Budget Limitations and 1\% Initiatives 1978-Present 1 (1998), available at http://tax.idaho.gov/pubs/EPB00107_01-01-1998.pdf.

98 Id. at $1-3$. 
Figure 1799

Property Tax

Idaho vs. Synthetic Control

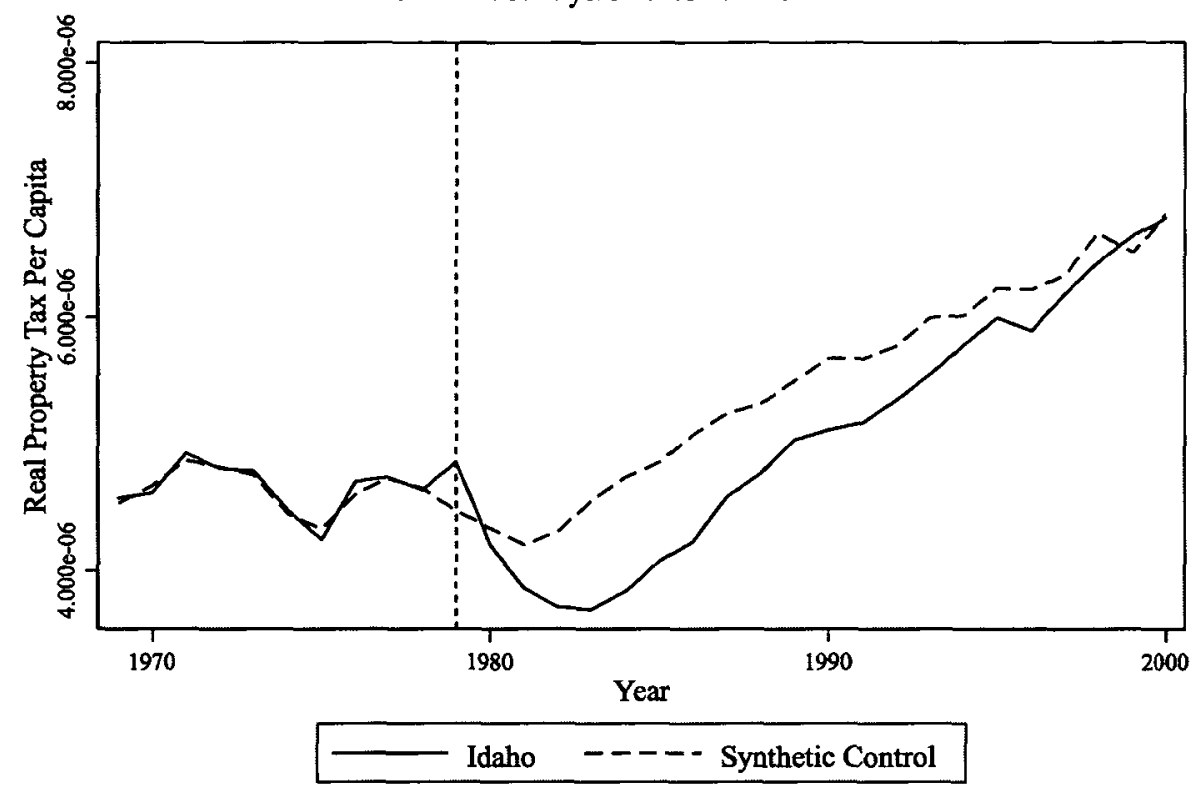

There appears to be an effect on property tax collections shortly after the implementation of this initiative. Idaho's real state and local property taxes per capita, however, increase faster than its synthetic counterfactual, eventually reaching a point where the two intersect. However, this effect is not significant, as shown in Figure 17, where Idaho's trajectory lies almost directly in the middle of the other placebo trajectories. There is very little reason to believe that there was any direct effect on property taxes here.

99 Data from U.S. Census Bureau, note 57. 
Figure 18

Idaho

Placebo Test-Property Tax

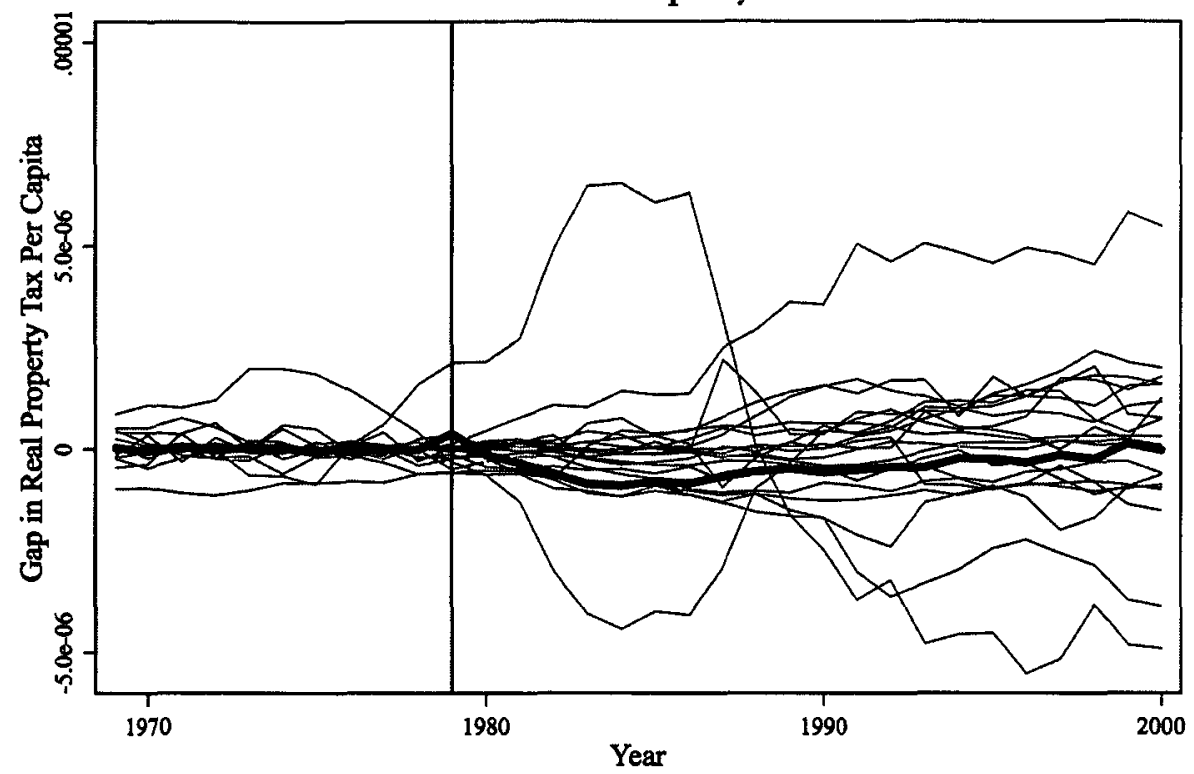

Note: Idaho's property tax trajectory is highlighted in bold.

Unsurprisingly, total tax revenue follows suit, as shown in Figure 18. The figure shows a similar dip, although not seemingly as large. Total tax revenue then remains under its synthetic control for the rest of the time series, much like property taxes did. It is noteworthy that Idaho provides an almost perfect pre-implementation match, with the average difference between Idaho and its synthetic control being 0.01 . 
FigURe 19

Total Tax Revenue

Idaho vs. Synthetic Control

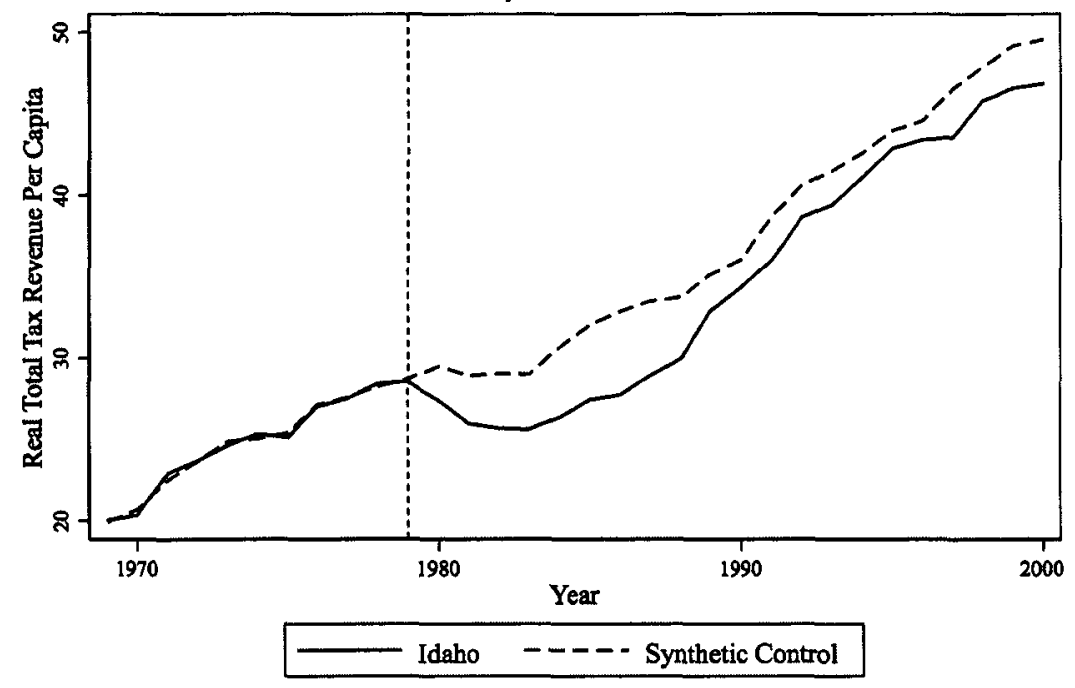

This effect is statistically significant, with a p-value of 0.05 . Figure 19 provides the placebo test figure for total tax revenue in Idaho.

Figure $20^{100}$

Idaho

Placebo Test-Total Tax Revenue

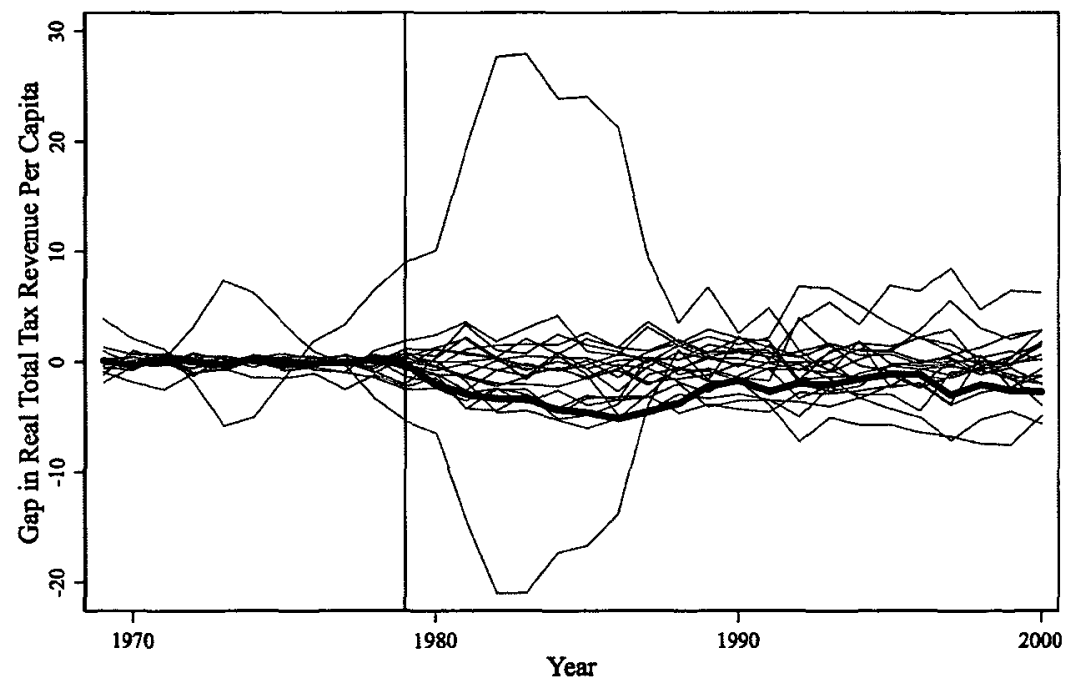

Note: Idaho's tax revenue trajectory is highlighted in bold.

100 Id. 
When looking at Figure 19, it is difficult to see why this effect is statistically significant, as it appears, like property taxes before it, to lie directly in the middle of the placebo distribution. It appears, however, that this result is driven almost entirely by the near perfect preimplementation match. Because the match is so close, it drives up the MSPE ratio relative to the placebo states, causing the effect to be very pronounced despite how unpronounced the effect itself seems. This is the same effect that seemed to drive Nevada away from significance. Instead, this time, despite the significance attached to this result, there is little reason to believe that there was any substantial effect here.

\section{Conclusion}

We theorized that requiring voter approval of tax impositions by the legislature would not change government fiscal behavior. Our synthetic case-control analysis confirms this theory. The behavior of the legislature rarely changes following the implementation of tax limitations. Likewise, government spending does not decrease, nor is debt reduced. This corroborates many recent stories about the nature of tax expenditure limitations in general: Tax expenditure limitations do not constrain government taxes or spending. Additionally, we also find evidence that even "success stories" such as Colorado's TABOR, do not demonstrate any of the notable effects that were attributed to them.

This work also has broader implications regarding the construction of effective governmental institutions. The often-conflicting interests that underpin the relationship between voters and their agents render the initiative process a weak institution. As voters lack the necessary means of enforcement, it is required that legislatures enforce the provisions in their stead. When legislatures are hostile to the provisions in a ballot measure, it is unlikely to be implemented as was intended by the voters. This is especially true in fiscal matters, whereby legislatures are incentivized to maintain or exceed current levels of taxes and expenditures. 